$12-31-2019$

\title{
State Ownership and Banks Information Rents: Evidence from China
}

Fengyan Ru

Qi Liang

Wei Wang

Cleveland State University, w.wang24@csuohio.edu

Follow this and additional works at: https://engagedscholarship.csuohio.edu/bus_facpub

Part of the Finance and Financial Management Commons

How does access to this work benefit you? Let us know!

Publisher's Statement

NOTICE: this is the author's version of a work that was accepted for publication in . Changes resulting from the publishing process, such as peer review, editing, corrections, structural formatting, and other quality control mechanisms may not be reflected in this document. Changes may have been made to this work since it was submitted for publication. A definitive version was subsequently published in Financial Review, 55, 2, (2019), 10.1111/fire.12197.

\section{Recommended Citation}

Ru, Fengyan; Liang, Qi; and Wang, Wei, "State Ownership and Banks Information Rents: Evidence from China" (2019). Business Faculty Publications. 280.

https://engagedscholarship.csuohio.edu/bus_facpub/280

This Article is brought to you for free and open access by the Monte Ahuja College of Business at EngagedScholarship@CSU. It has been accepted for inclusion in Business Faculty Publications by an authorized administrator of EngagedScholarship@CSU. For more information, please contact library.es@csuohio.edu. 


\title{
State ownership and banks' information rents: Evidence from China
}

\section{Fengyan Yu | Qi Liang | Wei Wang}

\begin{abstract}
In a lending relationship, a bank with an information advantage regarding its client tends to hold up the borrower and charge higher interest rates. We conjecture that state-owned enterprises (SOEs), with worse information asymmetry, are subject to greater information rents. State-owned banks place less emphasis on information production and hence extract lower rents compared to profitmaximizing private banks. We use the decline of loan interest rates around the borrowers' equity initial public offerings (IPOs) as the proxy of banks' information rents. We find SOEs in China experience larger declines in loan interest rates around their IPOs; the central government-controlled Big Four banks exhibit smaller declines in rates they charge, and their rate declines concentrate on loans made to SOEs.

KEYWORDS

banking relationship, information rent, IPO, loan interest rate, state ownership
\end{abstract}

\section{1 | INTRODUCTION}

The conventional wisdom about lending holds that banks are relationship lenders that acquire proprietary, firmspecific information about the borrowers through screening and monitoring services to overcome the information asymmetry (e.g., Allen, 1990; Diamond, 1984). A dark side of banks' information production is that it creates an information gap between incumbent banks and outside banks. A firm seeking to switch banks may be perceived by uninformed outsiders as a "lemon," regardless of its true financial condition. This gives incumbents monopoly power to "hold up" the borrowers and charge high interest rates (Rajan, 1992; Sharpe, 1990), especially when the firm lacks nonbank financing alternatives (Wu, Sercu, \& Yao, 2009). Recent studies, including Hale and Santos (2009), Schenone (2010), and Santos and Winton (2008), using loan data in the United States, provide empirical evidence of banks' information rents.

This paper, focusing on China's banking market where state-owned companies and banks are heavyweight players, seeks to understand how state ownership influences banks' rent extraction in such a market. In the same vein as Hale 
and Santos (2009) and Schenone (2010), we use the borrower firms' equity initial public offerings (IPOs) as the identification event to reveal the existence of pre-IPO rents. IPOs disseminate to the public a large amount of information about the issuers and, hence, erode incumbent banks' information advantage, forcing them to lower the loan interest rates. In addition, a firm's equity IPO expands its nonbank financing channels, further dissolving the banks' holdup power and the rents they can charge. Thus, the decline in loan interest rates around IPOs can be interpreted as the evidence of pre-IPO information rents.

We postulate that state ownership could impact the information rents in China's credit market due to two features of state ownership. First, the objective function of state-owned enterprises (SOEs) is not solely profit maximization; rather, it has a focus on providing social services (Baumol, 1984). Bai, Lu, and Tao (2006) contend that SOEs in China pursue two goals simultaneously: financial profits and social stability. For instance, they tend to avoid firing workers even in financial difficulties. This dual-objective problem baffles the efforts to monitor and evaluate SOE performance. Second, SOEs are owned by the public but controlled by politicians. The public ownership in SOEs is nontransferable, which "inhibits the capitalization of future consequences into current transfer prices, therefore reducing the incentive to detect and police managerial behavior" (De Alessi, 1974, p. 646). In addition, politicians have incentives to suppress firm-specific information to hide expropriation activities by them and their cronies (Shleifer \& Vishney, 1994).

Both the dual objectives and the separation of ownership (the public) and control (politicians) hinder monitoring and cause greater information asymmetry in SOEs. Consistent with this, prior research shows that state ownership is associated with lower financial reporting quality and financial transparency (Bushman, Piotroski, \& Smith, 2004; Guedhami, Pittman, \& Saffar, 2009). In a lending relationship, greater information barriers are more costly for potential competing banks to overcome, benefiting the incumbents consequently. Thus, we conjecture that SOEs would be subject to greater information rents in the credit market.

On the side of banks, the four largest commercial banks in China, ${ }^{1}$ often dubbed as the Big Four, are controlled by the central government; in contrast, other commercial banks have widely dispersed ownership structures often without a controlling owner (see Table A1 in the Appendix). Due to more severe dual-objective and separation of ownership and control problems than other banks, the Big Four's lending decision making is less likely based on borrowers' creditworthiness (Berger, Hasan, \& Zhou, 2009; lannotta, Nocera, \& Sironi, 2013; Sapienza, 2004). For this reason, the quantity and quality of proprietary information the Big Four acquire might be lower, and so would rents they are able to charge.

In summary, we make two hypotheses about the banks' rent extraction in China's credit market:

H1: Holding all else constant, SOEs are subject to greater information rents than non-SOE firms.

H2: Holding all else constant, the Big Four banks extract smaller information rents than non-Big Four banks.

The lending relationships between the Big Four banks and SOEs are especially interesting, as the common political and social goals could bring them into the loan transactions. In such SOE-Big Four transactions, impacts of state ownership on both parties would play a role in determining the cost of loans. On the one hand, the higher information asymmetry of SOEs impedes them from switching to alternative lenders, suggesting higher bank rents. On the other hand, the shared political and social goals further diminish the importance of information production, leading to lower bank rents. The net effect is thus an empirical issue. ${ }^{2}$

Our investigation is based on a proprietary, loan-level data set that spans the period May 1996 through December 2014. The data set contains detailed information of 10,543 traditional loans to private and public firms in China. In order to detect information rents in a bank-firm relationship, we compare the loan pricing before and after the

\footnotetext{
1 The Agricultural Bank of China, the China Construction Bank, the Bank of China, and the Industrial and Commercial Bank of China combined held about half of the industry assets during $2003-2012$ and made $60 \%$ of loans in our sample.

2 As an anonymous reviewer points out, additional factors to consider include government intervention and political connections. "Policy lending" between the Big Four and SOEs abounded in 1980s and early 1990 s whereby banks served as an intermediary to channel funds from the Central Bank to SOEs (Wei \& Wang, 1997). The Big Four-SOE lockup greatly loosened since 1990s as banks became more market-oriented (Cull \& Xu, 2003). Thus in our sample period (1996-2014), government intervention is relatively less relevant. Khwaja and Mian (2005), however, argue that political connections would still facilitate lending from the Big Four to SOEs. Anecdotes run that sometimes managers of SOEs faced political pressure to bor row from only the Big Four, or vice versa. The implication of political connections on the holdup problem, however, is again ambiguous as the pressure can be on either party.
} 
borrower's equity IPO. We measure the loan rate by the percentage interest rate spread-namely, the difference of a loan's interest rate from China's benchmark interest rates-as a percentage of the benchmark. ${ }^{3}$ Overall, SOEs exhibit a greater decline in the spread around IPOs (4.27\%) than non-SOEs (1.47\%). After controlling for loan, firm, and bank characteristics, an average SOE's spread decline is 1.58 percentage points greater than that of a non-SEO firm, consistent with our expectation. This translates into a difference of 9.5 basis points in interest rate decline if the benchmark rate is $6 \%$ (the average in our sample period). With similar controls, the declines in the Big Four's interest rate spreads around the borrowers' IPOs are on average 1.80 percentage points lower than those of non-Big Four banks, also consistent with our expectation. Out of Big Four loans, spread decline is markedly more pronounced for SOEs than for non-SOEs, indicating the Big Four fetch higher rents from the banking relationships with SOEs.

Competing, but not necessarily conflicting, interpretations of the loan rate declines around IPOs include IPO's risk effect and cash flow effect. The former holds that an equity IPO lowers the firm's debt ratio and financial risk, which in turn leads to lower credit cost (Hsu, Reed, \& Rocholl, 2010; Pagano, Panetta, \& Zingales, 1998). The latter argues that certification by investment banks (Carter \& Manaster, 1990) and increased investor recognition could lead to higher future cash flows and hence reduce credit cost. We control for these factors by incorporating capital structure, underwriter reputation, and analyst coverage in the model and obtain the same results.

Alternatively, the SOE versus non-SOE discrepancy in loan rate declines may arise due to ownership structure changes of SOEs. In an IPO, an SOE brings in new private owners, swaying the objective function toward profit maximization. This may drive the firm to more aggressively negotiate loan terms, resulting in a larger drop in loan rate. Inconsistent with this conjecture, though, we find that SOEs with an increase or a minor decrease in state ownership experience greater interest rate declines after IPO than those with a major decrease in state ownership. In addition, when we exclude those SOEs with a major drop in state ownership, we still find that SOEs experience significantly greater spread decline than non-SOEs. Hence, the interest rate decline is not attributable to the change in state ownership around IPOs.

We have considered the potential influence of interest rate liberalization in China on banks' information rents. ${ }^{4}$ Relaxation in interest rate regulation expands banks' pricing capacity, incentivizes their information production, and may ultimately entrench or compromise incumbent banks' holdup power. After controlling for the interest rate liberalization, our findings do not change. We also control for post-IPO information asymmetry of borrower firms and find the same results.

Our findings are also robust to alternative sample selections, with different periods around IPOs, including only firms that went public after one round of application, and with the restriction that sample loans are from the same banks around IPOs. In addition, we use the matched sample approach to control for the potential endogeneity of IPO decisions, and the results remain qualitatively unchanged.

Despite the accumulating evidence of banks' rent extraction, all investigations thus far consider developed markets in which profit-maximizing, privately held companies and banks are domiciled (e.g., Hale \& Santos, 2009; Schenone, 2010; Wu et al., 2009). Very little is known about how banks and borrowing firms interact to determine the cost of loans in an environment where either party may have incentives other than pursuing maximum profits. Our paper represents the first peek into the lending relationship confounded by government ownerships. It complements and extends the existing literature of relationship banking (Bharath, Dahiya, Saunders, \& Srinivasan, 2011; Degryse \& Van Cayseele, 2000; López-Espinosa, Mayordomo, \& Moreno, 2017; Petersen \& Rajan, 1994; Prilmeier, 2017), and explores yet another implication of state ownership in business management. While promoting social welfare, state ownership undercuts the efficiency of both banks and borrowing firms in that it weakens banks' incentive to information production and yet elevates firms' borrowing cost.

\footnotetext{
${ }^{3}$ The People's Bank of China (PBOC), China's central bank, set benchmark rates for loans that depend on macroeconomic conditions and loan maturity. Each benchmark rate supposedly accounts for the level of risk of loans in its category. Thus, the interest rate spread can be viewed as the risk-adjusted "abnor mal" rate. In China's banking market, loan rates were of ten quoted as certain percentage of the benchmark rates. Our use of percentage interest rate spread follows this practice. $X_{u}$, Rixtel, and Wang (2016) use the same measure.

${ }^{4}$ Commercial banks in China could set their lending rates between a floor rate and a ceiling rate during 1996-2004. The ceiling was removed in 2004 and the floor removed in 2013. See details of the evolving process of interest rate regulation in China in Section 2.
} 
The rest of the paper is organized as follows. Section 2 provides the background of the Chinese banking market. Section 3 describes our variables and methodology. Section 4 presents the main results. Section 5 concludes the paper.

\section{I AN OVERVIEW OF CHINA'S BANKING MARKET}

Government intervention in the credit market is perceived as very common in China (Berger et al., 2009; Jia, 2009). For a long time, PBOC, the central bank in China, limited commercial banks' pricing capacity on loans by regulating interest rates. Prior to May 1996, lending institutions had to provide credit at the exact interest rates mandated by the PBOC. During May 1996 through October 2004, the central bank set benchmark interest rates for loans of different maturities as well as designated both ceilings and floors for those rates. For instance, in May 1996, the benchmark interest rate for a 1 year loan is $10.98 \%$, and the ceiling (floor) rate for loans made by commercial banks to small-sized enterprises is $110 \%$ (90\%) of the benchmark. Market rates set by commercial banks had to float within such regulatory bands. The interest rate bands were expanded a few times during this period, before the ceilings on interest rates were removed in October 2004. In July 2013, floors were removed for all bank loans, and banks gained full pricing capacity.

Another salient characteristic of China's banking sector is the preeminent position of the four largest, state-owned commercial banks. According to the 2015 Almanac of China's Finance and Banking, ${ }^{5}$ during 2010-2014 the Big Four on average owned over $40 \%$ of industry assets. Other players in China's credit market include 12 joint-stock commercial banks, city commercial banks, rural credit unions, and others. The Big Four differ from other players not only in size but also in ownership structure (Table A1 in the Appendix). The actual controller of the Big Four banks is the central government (Ministry of Finance), while non-Big Four banks have no controlling owner or are controlled by provincial or city governments, enterprises, or individual investors. Bai et al. (2006) argue that compared with local governments, central governments care more about social stability and impose a higher level of restrictions and intervention on affiliated banks. In addition, Gao, Wang, Yang, and Zhao (2017) show that the average state ownership of the Big Four is more than 10 times of that of non-Big Four banks. The contrast in ownership structure means the Big Four banks are subject to substantially more political interference and behave less like profit maximizers (Barth, Caprio, $\mathcal{\&}$ Levine, 2004; Ferri, 2009; La Porta, Lopez-de-Silanes, \& Shleifer, 2002).

\section{3 | DATA AND VARIABLES}

\section{1 | Data}

The sample construction starts with identifying the 1,704 IPOs on the Shanghai Stock Exchange and Shenzhen Stock Exchange between 1999 and 2012. We then manually collect these firms' loan data around their IPOs. The pre-IPO loan data are obtained from IPO prospectuses and the post-IPO loan data from these companies' annual reports. We collect loan data for only the 3 years immediately following the IPO, because Pagano et al. (1998) find that the information effects of IPO hold for no more than 3 years. For symmetry, we use pre-IPO loan data during the 3 years prior to the IPO. The sample thus obtained is the first ever to have loan-level price information on China's credit market. ${ }^{6}$

We complement the loan data with the firm-specific information from the CSMAR database and the Wind database, as well as bank-specific information from the BankScope database.

Following Hale and Santos (2009) and Schenone (2010), we exclude 32 financial firms, 947 firms with only pre- or post-IPO loans, and 230 firms for which our control variables are missing. This leaves us 10,543 loans for 495 IPO firms during 1996-2014, with an average of about 21 loans per firm. Of these loans, 5,491 (52.08\%) are made pre-IPO,

\footnotetext{
5 Almanac of China's Finance and Banking, Almanac of China's Finance and Banking Editorial Board. http://tongji.cnki.net/kns55/navi/HomePage.aspx?id=N 2018070031\&name $=$ YXCVB\&floor $=1$

${ }^{6}$ Extant studies on Chinese loan markets use yearly aggregate firm-level data from the China Stock Market and Accounting Research (CSMAR) database (e.g., Chen, Lobo, Wang, \& Yu, 2013) rely on loan-level data sets provided by a few state-owned banks (Chang, Liao, Yu, \& Ni, 2014; Qian, Strahan, \& Yang, 2015), or focus on nonprice terms of the post-IPO loan contracts (Gao et al., 2017; Xu et al., 2016).
} 
and 5,052 (47.92\%) are made post-IPO; 3,690 (35.00\%) are borrowed by SOEs, and the rest by nonstate-owned firms; $6,395(60.66 \%)$ are made by the Big Four banks, and the rest by the non-Big Four banks. Table A2 in the Appendix shows the distribution of loans in various categories.

\section{2 | Variables}

Our main interest lies in the change in interest rates on bank loans around IPOs. Instead of the actual interest rate, we focus on the percentage spread (Spread), measured as the difference in interest rate from the benchmark interest rate set by the PBOC as a percentage of the benchmark rate. Because the benchmark rate reflects the PBOC's assessment of market conditions and differs for loans of different maturities, the spread can be roughly viewed as the risk-adjusted "abnormal" rate. It is calculate as:

$$
\text { Spread }=\frac{\text { Actual interest rate }- \text { Benchmark interest rate }}{\text { Benchmark interest rate }} * 100 .
$$

To capture the interest rate changes around IPOs, we create a dummy variable, PostIPO, which takes the value of 1 for a loan made after the borrower firm's IPO. We also use two dummy variables to denote different types of borrowers and lenders: SOE is equal to 1 for loans of state-owned firms; Big4 is equal to 1 for loans made by the Big Four banks.

In the baseline model, we control for major loan, firm, and bank relationship characteristics that are known to influence interest rates. Loan characteristics include the maturity (Maturity), the loan amount (Amount), and whether a loan is secured (Secured). Secured is equal to 1 if a loan has collaterals or guarantors. Firm characteristics include firm age (Age), size (Size), asset tangibility (Tangible), investment return (ROA), financial leverage (Leverage), and earnings volatility (Earnings volatility). Size is measured as the logarithm of total assets in millions of constant RMB yuan of the year 1990. Asset tangibility is the sum of inventories and plant, property, and equipment as a ratio to total assets. Financial leverage is total debt over assets, controlling for the decline in financial risk of the borrower firm around IPO thanks to the equity capital raised. Following Boubakri, Cosset, and Saffar (2013), earnings volatility is found as standard deviation of operating profit margin (EBIT/Assets) in rolling periods of three preceding years and proxies for the borrower's operating risk.

We measure a firm's banking relationship with the following two variables. At the bank level, we follow Schenone (2010) to define Relationship intensity as the number of loans a bank has made to the firm as a ratio to the total number of loans the firm has received from all banks. At the firm level, we measure its Loan concentration in a year as the Herfindahl-Hirschman Index $(\mathrm{HHI})$ of bank shares. $\mathrm{HHI}$ proxies for the intensity of competition among banks for a firm's business; a higher HHI value corresponds to less competition for incumbent banks.

We control for the changes in China's credit market conditions mainly using three dummy variables: Liberalization I, Liberalization II, and Recession. The first two capture the process of interest rate liberalization in China during the sample period. Liberalization / is equal to 1 for loans taken after the PBOC removed the interest rate ceilings for commercial bank loans on October 28, 2004, but before rate floors were removed on July 19, 2013. Liberalization I/ is equal to 1 for loans after July 19, 2013. Recession is equal to 1 for loans taken in recession periods. Santos and Winton (2008) and Mattes, Steffen, and Wahrenburg (2013) show that banks take greater rents when increased uncertainty magnifies the difficulties of outside capital suppliers in evaluating the quality of borrowers. Following them, we identify two recession periods using the Early Warning Index of Macroeconomic Climate, ${ }^{7}$ respectively from July 1997 to October 2002, and from January 2012 to December 2014.

Table 1 provides detailed variable definitions. Statistic summary of the variables in our sample is presented in Table 2. The actual interest rate averages $6.036 \%$ and ranges between $0.6 \%$ and $14.94 \%$. Spread on average is negative at -0.114 , indicating the actual loan rates are merely $0.114 \%$, or 0.7 basis points, lower than the average benchmark rate. The median spread is zero. However, actual rates can widely deviate from the benchmark, with the spread ranging

\footnotetext{
${ }^{7}$ The Early Warning Index of Macroeconomic Climate, from the Wind database, is a monthly index that measures the probability with which the economy is in a recession using three categories of economic variables after the removal of measurement errors as well as seasonal and other short-term fluctuations. In the same vein as Santos and Winton (2008) and Mattes et al. (2013), we identify a recession as a period when the Early Warning Index is below its long-run average for at least four consecutive quarters.
} 
TABLE 1 Variable definitions

\begin{tabular}{|c|c|}
\hline Variable & Definition \\
\hline Actual interest rate & The loan's raw interest rate \\
\hline Spread & $\begin{array}{l}\text { The difference of a loan interest rate from the benchmark interest rate set by } \\
\text { the People's Bank of China, expressed as a percentage of the benchmark } \\
\text { rate }\end{array}$ \\
\hline PostIPO & A dummy variable, equal to 1 for loans after the firm's equity IPO \\
\hline SOE & $\begin{array}{l}\text { A dummy variable, equal to } 1 \text { if the ultimate controlling shareholder of a } \\
\text { borrower is the central government or a local government }\end{array}$ \\
\hline Big4 & $\begin{array}{l}\text { A dummy variable, equal to } 1 \text { for the loans made by the four first-tier } \\
\text { commercial banks in China that are controlled by the central government }\end{array}$ \\
\hline \multicolumn{2}{|l|}{ Loan characteristics } \\
\hline Maturity & Loan maturity, measured in years \\
\hline Amount & $\begin{array}{l}\text { The log of } 1 \text { plus loan amount, where the loan amount is in millions of constant } \\
\text { RMB yuan of the year } 1990\end{array}$ \\
\hline Secured & A dummy variable, equal to 1 if the loan has collaterals or guarantors \\
\hline \multicolumn{2}{|l|}{ Firm characteristics } \\
\hline Age & The number of years since incorporation \\
\hline ROA & Net income divided by assets \\
\hline Tangible & Inventories plus plant, property, and equipment over assets \\
\hline Size & Log of assets in millions of constant RMB yuan of the year 1990 \\
\hline Leverage & Total debt over assets \\
\hline Earnings volatility & $\begin{array}{l}\text { The standard deviation of EBIT-to-asset ratio in rolling periods of three } \\
\text { preceding years }\end{array}$ \\
\hline \multicolumn{2}{|c|}{ Banking relationship characteristics } \\
\hline Loan concentration & The Herfindahl-Hirschman Index (HHI) of bank loans for a firm in a year \\
\hline Relationship intensity & $\begin{array}{l}\text { The number of a firm's historical loans from a bank as a ratio of the total } \\
\text { number of the firm's historical loans (Schenone, 2010) }\end{array}$ \\
\hline \multicolumn{2}{|l|}{ Time variables } \\
\hline Liberalization ! & $\begin{array}{l}\text { A dummy variable, equal to } 1 \text { for loans taken after October } 28,2004 \text {, when } \\
\text { the PBOC removed the ceiling for commercial bank interest rates, and } \\
\text { before July } 19,2013 \text {, when the PBOC completely removed the restrictions } \\
\text { on interest rates }\end{array}$ \\
\hline Liberalization $/ 1$ & $\begin{array}{l}\text { A dummy variable, equal to } 1 \text { for loans taken after July } 19,2013 \text {, when the } \\
\text { PBOC completely removed the restrictions on interest rates }\end{array}$ \\
\hline Recession & $\begin{array}{l}\text { A dummy variable, equal to } 1 \text { for loans taken during recession periods, July } \\
1997 \text { to October 2002, and January } 2012 \text { to December } 2014\end{array}$ \\
\hline \multicolumn{2}{|c|}{ Information asymmetry variables } \\
\hline Underwriter reputation & $\begin{array}{l}\text { Market share, in percentages, of the IPO lead underwriter in China's IPO } \\
\text { market during the year }\end{array}$ \\
\hline Analyst coverage & $\begin{array}{l}\text { Log of } 1 \text { plus the average number of analysts following the firm in the } 3 \text { years } \\
\text { after its IPO }\end{array}$ \\
\hline Disclosure violation & $\begin{array}{l}\text { A dummy variable, equal to } 1 \text { if a firm is criticized for or charged with } \\
\text { violations of information disclosure regulations by the stock exchange } \\
\text { where its stocks trade, or by the China Securities Regulatory Commission } \\
\text { (CSRC) in the }[-3,3] \text { event window }\end{array}$ \\
\hline Earning quality & $\begin{array}{l}\text { Abnormal total accrual, where total accruals are the change in noncash } \\
\text { working capital before income taxes payable less total depreciation } \\
\text { expense. Take total accruals of prior period ( } t-1) \text { as "normal" total accrual, } \\
\text { thus the "abnormal" total accrual is the difference between current and } \\
\text { normal total accruals }\end{array}$ \\
\hline
\end{tabular}


TABLE 2 Summary statistics

\begin{tabular}{|c|c|c|c|c|c|c|}
\hline Variable & Mean & Median & $S D$ & Min & Max & Obs. \\
\hline Actual interest rate & 6.036 & 5.900 & 1.447 & 0.600 & 14.940 & 9,857 \\
\hline Spread & -0.114 & 0.000 & 7.011 & -66.930 & 50.000 & 10,543 \\
\hline PostiPo & 0.479 & 0.000 & 0.500 & 0.000 & 1.000 & 10,543 \\
\hline SOE & 0.350 & 0.000 & 0.477 & 0.000 & 1.000 & 10,543 \\
\hline Big4 & 0.606 & 1.000 & 0.488 & 0.000 & 1.000 & 10,543 \\
\hline \multicolumn{7}{|l|}{ Loan characteristics } \\
\hline Maturity & 2.047 & 1.000 & 2.174 & 0.017 & 25.000 & 10,543 \\
\hline Amount (million yuan) & 41.810 & 135.110 & 15.310 & 0.020 & $4,402.760$ & 10,543 \\
\hline Secured & 0.744 & 1.000 & 0.437 & 0.000 & 1.000 & 10,543 \\
\hline \multicolumn{7}{|l|}{ Firm characteristics } \\
\hline Age & 6.781 & 5.920 & 4.656 & 0.001 & 26.500 & 9,656 \\
\hline$R O A$ & 0.078 & 0.064 & 0.091 & -1.153 & 1.418 & 9,656 \\
\hline Tangible & 0.427 & 0.398 & 0.222 & 0.002 & 0.974 & 9,656 \\
\hline Size (million yuan) & 4,247 & 11,993 & 1,564 & 75 & 136,752 & 9,656 \\
\hline Leverage & 0.447 & 0.458 & 0.166 & 0.004 & 0.943 & 9,656 \\
\hline Earnings volatility & 0.104 & 0.089 & 0.077 & 0.013 & 0.811 & 9,656 \\
\hline \multicolumn{7}{|c|}{ Bank relationship variables } \\
\hline Loan concentration & 0.338 & 0.273 & 0.275 & 0.000 & 1.000 & 10,543 \\
\hline Relationship intensity & 0.404 & 0.333 & 0.310 & 0.000 & 1.000 & 10,543 \\
\hline \multicolumn{7}{|l|}{ Time variables } \\
\hline Liberalization 1 & 0.696 & 1.000 & 0.460 & 0.000 & 1.000 & 10,543 \\
\hline Liberalization II & 0.019 & 0.000 & 0.136 & 0.000 & 1.000 & 10,543 \\
\hline Recession & 0.234 & 0.000 & 0.424 & 0.000 & 1.000 & 10,543 \\
\hline
\end{tabular}

Note. The sample includes 10,543 loans during 1996-2014 for 495 firms that had their IPOs during 1999-2012. This table reports summary statistics for loan, firm, banking relationship characteristics, and time variables. Variables are as defined in Table 1. Loan amount and firm size (total assets) are in millions of constant RMB yuan of the year 1990.

from $-66.93 \%$ to $50 \%$. About $48 \%$ of loans in our sample are made after borrowers' IPOs. SOEs take $35 \%$ of the loans, and the Big Four make $60.6 \%$ of the loans. Loan maturity ranges from about a week $(0.017)$ to 25 years, with an average of about 2 years and a median of 1 year. Thus, roughly half of the loans are short-term loans. The average loan amount is 41.81 million yuan. About three-fourths of the loans are either collateralized or guaranteed.

An average borrower firm is 6.781 years old, with total assets of 4.247 billion yuan and an ROA of $7.8 \%$. Tangible assets and debt account for $42.7 \%$ and $44.7 \%$, respectively, of the firm's total assets. Earnings volatility averages 0.104 .

The $\mathrm{HHI}$ measuring loan concentration at the firm level averages 0.338 , ranging from nearly 0 to 1 . Relationship intensity has a mean of 0.404 , indicating that for an average loan, its bank has made two loans out of every five loans the firm has received.

\section{I RESULTS}

\subsection{Changes in loan characteristics and banking relationship around the IPO: A first look}

Table 3, Panel A, presents the comparison of loan spread and other characteristics around borrowers' IPOs. Pre-IPO loans have on average a positive spread of $0.989 \%$, while post-IPO loans' average spread is negative at $-1.314 \%$, representing a decline of 2.303 percentage points that is statistically significant at the $1 \%$ level. If the benchmark rate is $6 \%$, 
TA B LE 3 Loan characteristics and banking relationships: Pre-versus post-IPO

\begin{tabular}{|c|c|c|c|c|c|}
\hline \multicolumn{5}{|c|}{ Panel A: Loan characteristics } & $t$-Value \\
\hline \multicolumn{6}{|l|}{ Spread } \\
\hline All loans & -0.114 & 0.989 & -1.314 & $-2.303^{*+4}$ & -6.923 \\
\hline SOE & -0.566 & 1.119 & -3.154 & $-4.274^{* * *}$ & -7.182 \\
\hline Non-SOE & 0.129 & 0.900 & -0.570 & $-1.470^{* * *}$ & -3.637 \\
\hline \multicolumn{6}{|c|}{ Maturity (years) } \\
\hline All loans & 2.046 & 1.749 & 2.370 & $0.621^{* * *}$ & 14.801 \\
\hline SOE & 2.328 & 2.132 & 2.628 & $0.496^{* * *}$ & 6.099 \\
\hline Non-SOE & 1.895 & 1.486 & 2.265 & $0.779^{* * *}$ & 16.348 \\
\hline \multicolumn{6}{|l|}{ Amount } \\
\hline All loans & 1.236 & 1.142 & 1.337 & $0.196^{* * *}$ & 19.672 \\
\hline SOE & 1.192 & 1.020 & 1.454 & $0.434^{* * *}$ & 22.166 \\
\hline Non-SOE & 1.259 & 1.225 & 1.290 & $0.065^{* * *}$ & 5.911 \\
\hline \multicolumn{6}{|l|}{ Secured } \\
\hline All loans & 0.744 & 0.785 & 0.698 & $-0.087^{* * *}$ & -10.310 \\
\hline SOE & 0.713 & 0.782 & 0.607 & $-0.175^{* * *}$ & -11.708 \\
\hline Non-SOE & 0.760 & 0.788 & 0.735 & $-0.053^{* * *}$ & -5.118 \\
\hline \multicolumn{6}{|c|}{ Panel B: Banking relationship variables } \\
\hline \multicolumn{6}{|c|}{ Loan concentration } \\
\hline All loans & 0.338 & 0.356 & 0.318 & $-0.038^{* * *}$ & -7.128 \\
\hline SOE & 0.316 & 0.339 & 0.279 & $-0.060^{* * *}$ & -6.329 \\
\hline Non-SOE & 0.350 & 0.368 & 0.333 & $-0.035^{* * *}$ & -5.356 \\
\hline \multicolumn{6}{|c|}{ Relationship intensity } \\
\hline All loans & 0.404 & 0.427 & 0.378 & $-0.050^{* * *}$ & -8.307 \\
\hline SOE & 0.441 & 0.483 & 0.376 & $-0.106^{* * *}$ & -9.863 \\
\hline Non-SOE & 0.384 & 0.390 & 0.378 & -0.012 & -1.611 \\
\hline
\end{tabular}

Note. This table presents the comparison in loan characteristics and banking relationship variables between pre-IPO and postIPO subsamples. The mean values are presented for all loans, and for loans of SOEs and those of non-SOEs, in the full sample period, and in the pre-IPO period and post-IPO period, separately. $t$-Tests are conducted to test the differences between the pre-IPO means and the post-IPO means.

****,*** indicate statistical significance at the $.01, .05$ and .10 level, respectively.

then such a decline amounts to 14 basis points. According to the literature, this decline in loan spread is indicative of the holdup rents banks charge. For loans of SOEs, this decline in spread is 4.274 percentage points, much larger than that for loans of non-SOEs (1.470 percentage points), consistent with our conjecture that SOEs suffer from greater bank rents. After a firm goes public, loan maturity lengthens and the amount increases, and fewer loans need collaterals or guarantees, all consistent with IPOs moderating information asymmetry of issuing companies.

Panel B presents the changes in banking relationship characteristics around IPOs. An average firm's loan concentration $(\mathrm{HHI})$ is 0.356 prior to its IPO, which declines to 0.318 after the IPO. Relationship intensity also declines from 0.427 to 0.378 . Thus, a firm uses loans from a larger number of banks post-IPO, as predicted by the theory. SOEs exhibit lower loan concentration but greater relationship intensity with banks, indicating that SOEs maintain longer-term relationships with a larger number of banks. Notably, the decline in SOEs' loan concentration (-0.060) around IPO is more pronounced than that for non-SOE firms (-0.035); relationship intensity also declines more for SOEs than for non-SOE 
TA B LE 4 Comparison of SOEs and non-SOEs in the pre-IPO period

\begin{tabular}{|c|c|c|c|c|}
\hline & SOE & Non-SOE & Difference & $t$-Value \\
\hline \multicolumn{5}{|l|}{ Loan characteristics } \\
\hline Spread & 1.119 & 0.900 & 0.219 & 0.480 \\
\hline Maturity & 2.132 & 1.486 & $0.646^{* * *}$ & 12.210 \\
\hline Amount & 1.023 & 1.225 & $-0.202^{* * *}$ & -15.921 \\
\hline Secured & 0.785 & 0.788 & -0.006 & -0.531 \\
\hline \multicolumn{5}{|l|}{ Firm characteristics } \\
\hline Age & 4.300 & 6.898 & $-2.598^{* * *}$ & -20.232 \\
\hline Size & 3.186 & 3.081 & $0.105^{* * *}$ & 9.320 \\
\hline ROA & 0.057 & 0.117 & $-0.060^{* * *}$ & -28.261 \\
\hline Tangible & 0.361 & 0.412 & $-0.051^{* * *}$ & -8.723 \\
\hline Leverage & 0.491 & 0.480 & $0.011^{* *}$ & 2.465 \\
\hline Earnings volatility & 0.052 & 0.041 & $0.011^{* * *}$ & 4.165 \\
\hline \multicolumn{5}{|c|}{ Banking relationship variables } \\
\hline Loan concentration & 0.339 & 0.368 & $-0.029^{* * *}$ & -3.935 \\
\hline Relationship intensity & 0.483 & 0.390 & $0.093^{* * *}$ & 10.626 \\
\hline
\end{tabular}

Note. This table compares loan characteristics, firm characteristics, and banking relationship variables between SOEs and nonSOEs in the pre-IPO period. The firm, loan, and bank relationship variables are as defined in Table 1. For each variable, the difference in mean between SOEs and non-SOEs is reported and tested using a t-test.

******, * indicate statistical significance at the $.01, .05$ and .10 level, respectively.

firms (-0.106 vs. -0.012). These comparisons all point to that SOEs' borrowing opportunities improve after the IPO by a larger degree than non-SOE firms, indicating that the holdup problem is more severe for SOEs pre-IPO.

It is also interesting to know if the differences between SOEs and non-SOEs are significant in the pre-IPO period. In Table 4, we present the comparison of loan, firm, and bank relationship characteristics between SOEs and non-SOEs in the pre-IPO period. On average, SOE borrowers have slightly higher interest rates than non-SOE borrowers, but the difference is not statistically significant. SOEs' loans are smaller in amount and longer in maturity, and about equally likely to be secured. SOEs and non-SOEs are significantly different in firm characteristics and banking relationship variables. On average, SOEs are younger, larger, less profitable, with higher financial leverage and less tangible assets. They also feature greater earnings volatility in the pre-IPO period. Just like in the whole period, SOEs exhibit lower loan concentration but greater relationship intensity with banks. These distinctions point to the importance of accounting for firm, loan, and banking relationship variables in examining bank rents.

\section{2 | State ownership and loan rates around IPO: Main results}

Table 5 reports the first set of multivariate tests that investigate the relationship between SOEs and information monopoly rent in H1. We estimate the following model:

$$
\text { Spread }_{i j t}=\alpha_{i}+\gamma_{t}+\beta_{1} \text { PostIPO }_{i j t}+\beta_{2} S E_{i t}+\beta_{3} P_{\text {ostIPO }} \times \operatorname{SOE}_{i t}+\delta \text { Controls }+\varepsilon_{i j t},
$$

where $i, j$, and $t$ are subscripts for the borrower firm, the lending bank, and year of the loan, respectively. The dependent variable is the interest rate spread. Main explanatory variables are PostIPO (the indicator of a post-IPO loan), SOE (the indicator of an SOE), and their interaction. Control variables include loan characteristics, firm characteristics, banking relationship characteristics, and time variables. Firm and year fixed effects are controlled for.

We first run the regression without the SOE indicator and the interaction term in the full sample and report the result in column 1. PostIPO, the variable of interest, receives a negative coefficient of -1.415 , statistically significant 
TA B LE 5 State ownership and loan rates around IPOS

\begin{tabular}{|c|c|c|c|c|}
\hline & $\begin{array}{l}\text { All } \\
\text { (1) }\end{array}$ & $\begin{array}{l}\text { SOE } \\
(2)\end{array}$ & $\begin{array}{l}\text { Non-SOE } \\
\text { (3) }\end{array}$ & $\begin{array}{l}\text { All } \\
\text { (4) }\end{array}$ \\
\hline \multirow[t]{2}{*}{ PostlPO $_{i j \mathrm{t}}$} & $-1.415^{* * x}$ & $-3.059^{* * *}$ & -0.857 & $-0.972^{*}$ \\
\hline & $(-2.80)$ & $(-3.02)$ & $(-1.42)$ & $(-1.71)$ \\
\hline \multirow[t]{2}{*}{$\mathrm{SOE}_{i t}$} & & & & -1.426 \\
\hline & & & & $(-1.33)$ \\
\hline \multirow[t]{2}{*}{$S O E_{i t} \times P_{o s t} P O_{i j t}$} & & & & $-1.575^{* * *}$ \\
\hline & & & & $(-2.70)$ \\
\hline \multirow[t]{2}{*}{ Maturity $_{i j t}$} & $-1.084^{* * *}$ & $-1.006^{* * *}$ & $-1.174^{* * *}$ & $-1.093^{* * * *}$ \\
\hline & $(-11.47)$ & $(-6.62)$ & $(-9.36)$ & $(-11.55)$ \\
\hline \multirow[t]{2}{*}{ Amount $_{i j t}$} & -0.234 & $-1.975^{* * *}$ & 0.711 & -0.207 \\
\hline & $(-0.61)$ & $(-3.02)$ & (1.51) & $(-0.54)$ \\
\hline \multirow[t]{2}{*}{ Secured $_{i j t}$} & $3.106^{* * *}$ & $4.296^{* * *}$ & $2.605^{* * *}$ & $3.083^{* * *}$ \\
\hline & (7.42) & $(5.12)$ & (5.38) & (7.36) \\
\hline \multirow[t]{2}{*}{$A g e_{i t-1}$} & -0.219 & $2.028^{* * *}$ & $-1.417^{* * *}$ & -0.204 \\
\hline & $(-0.52)$ & $(2.74)$ & $(-2.75)$ & $(-0.48)$ \\
\hline \multirow[t]{2}{*}{$\operatorname{Size}_{i t-1}$} & $3.349^{* *}$ & $8.351^{* *}$ & 0.254 & $2.963^{* *}$ \\
\hline & $(2.30)$ & $(2.10)$ & $(0.16)$ & (2.01) \\
\hline \multirow[t]{2}{*}{$\mathrm{ROA}_{\text {it }-1}$} & -4.668 & -1.662 & -3.580 & -4.106 \\
\hline & $(-1.45)$ & $(-0.14)$ & $(-1.07)$ & $(-1.27)$ \\
\hline \multirow[t]{2}{*}{ Tangible $_{i t-1}$} & $4.170^{* *}$ & -2.515 & $6.598^{* *}$ & $3.968^{* *}$ \\
\hline & $(2.24)$ & $(-0.87)$ & $(2.38)$ & (2.13) \\
\hline \multirow[t]{2}{*}{ Leverage $_{i t-1}$} & $5.454^{* * x}$ & $11.979^{* * *}$ & $5.554^{*}$ & $5.635^{* * *}$ \\
\hline & $(2.76)$ & (3.52) & $(1.93)$ & $(2.85)$ \\
\hline \multirow[t]{2}{*}{ Earnings volatility } & $4.709^{* *}$ & $6.099^{*}$ & 3.013 & $3.893^{*}$ \\
\hline & $(2.02)$ & $(1.66)$ & $(1.58)$ & $(1.90)$ \\
\hline \multirow[t]{2}{*}{ Loan concentration $_{i t}$} & $1.503^{*}$ & 0.755 & $2.611^{* *}$ & $1.377^{*}$ \\
\hline & $(1.81)$ & $(0.51)$ & (2.53) & $(1.66)$ \\
\hline \multirow[t]{2}{*}{ Relationship intensity $_{i j t}$} & 0.014 & -1.433 & 0.917 & 0.032 \\
\hline & $(0.02)$ & $(-1.41)$ & $(1.34)$ & $(0.06)$ \\
\hline \multirow[t]{2}{*}{ Recession $_{i j t}$} & $4.984^{* * x}$ & $4.351^{* * *}$ & 8.199 & $4.670^{* * *}$ \\
\hline & (3.75) & (3.07) & $(1.28)$ & (3.48) \\
\hline Constant & Yes & Yes & Yes & Yes \\
\hline Firm fixed effects & Yes & Yes & Yes & Yes \\
\hline Year fixed effects & Yes & Yes & Yes & Yes \\
\hline$N$ & 9,656 & 3,112 & 6,544 & 9,656 \\
\hline$R^{2}$ & 0.449 & 0.437 & 0.467 & 0.450 \\
\hline
\end{tabular}

Note. This table presents the fixed-effects estimation of the regressions of interest rate spread on explanatory variables. The sample includes 10,543 loans for 495 firms during 1996-2014. For each firm, all loans in the 3 years prior to the IPO and the 3 years post-IPO are included. The dependent variable is Spread, the percentage interest rate spread relative to the benchmark interest rates. PostIPO is equal to 1 for a loan taken after the firm's IPO. SOE is equal to 1 for a firm whose ultimate controlling shareholder is the government. $t$-Statistics are reported in parentheses.

${ }^{* * *},{ }^{* *},{ }^{*}$ indicate statistical significance at the $.01, .05$ and .10 level, respectively. 
at the $1 \%$ level. It indicates that holding all else constant, an average firm's loan spread declines by 1.415 percentage points after its IPO. Assuming a $6 \%$ benchmark interest rate, this represents a rate decline of 8.5 basis points. As the IPO disseminates a large amount of information to the credit market as well as provides alternative nonbank financing channels, we interpret this rate decline as evidence of the holdup problem and banks' rent extraction prior to the borrower IPOs in China's banking market.

To examine whether state ownership influences bank rents, we run the same regression in the subsample of SOE loans and non-SOE loans separately and report the results in columns 2 and 3 . In the SOE subsample, the coefficient on PostIPO is -3.059 , statistically significant at the $1 \%$ level; in contrast, in the non-SOE subsample, this coefficient is much lower in magnitude, -0.857 , which is not statistically different from zero. This contrast indicates SOEs suffer from more severe holdup problem, consistent with our hypothesis.

To verify this finding, we estimate Equation (2), bringing in the SOE indicator and its interaction with POStIPO. Column 4 presents the results. PostIPO receives a coefficient of -0.972 , which is of marginal significance statistically. This coefficient captures the information rents charged on non-SOE borrowers. The coefficient on SOE is negative but not statistically different from zero. Thus on average, SOEs and non-SOEs do not differ in loan rate spread. The interaction term between SOE and PostIPO obtains a negative and statistically significant coefficient of -1.575 , capturing the difference between SOEs and non-SOE firms in spread decline around the IPOs, corroborating the subsample regression results. Assuming a $6 \%$ benchmark interest rate, this coefficient indicates that the raw interest rate decline around IPO for SOEs is 9.5 basis points larger than for non-SOEs. In short, the results show that firms are able to borrow from banks at lower interest rates after their equity IPOs, and SOEs enjoy greater interest rate declines than their non-SOE peers, consistent with our hypothesis.

Most control variables load in the regressions, speaking for their impacts on cost of bank loans. The percentage spread is negatively associated with the loan maturity. This relationship is probably mechanical because a same raw spread represents a smaller percentage spread for a longer term loan with a greater benchmark interest rate. The spread decreases as the loan amount increases, consistent with the economies of scale in loan size (Hale \& Santos, 2009). Secured obtains a negative coefficient, because collaterals and guarantees are sought for only riskier credits (e.g., Berger \& Udell, 1990).

The signs of the slopes for firm characteristics show that firms with more tangible assets and lower leverage enjoy lower interest rates. It is worth noting that the inclusion of financial leverage controls for the decline in financial risk after the IPO raises equity capital. Earnings volatility and loan concentration both load positively, indicating that riskier firms and firms facing low bank competition pay higher cost for their loans. Relationship intensity does not load. A potential interpretation is that loan concentration is an alternative measure of the strength of banking relationship, which subsumes the effect of relationship intensity observed in Schenone (2010).

\section{3 | Robustness checks}

\subsection{1 | Alternative samples}

\section{Shorter periods around IPOs}

We check the robustness of the above results using alternative samples. First, we shorten the width of window for each sample firm from six years around its IPO - that is, 3 years pre-IPO and 3 years post-IPO or the $[-3,3]$ period - to 2 years around the IPO - that is, 1 year pre-IPO and 1 year post-IPO or the $[-1,1]$ period. This change shrinks the sample size, but minimizes the variations in loan interest rate attributable to factors not related to the IPO effect. We run the same regressions as above and report the results in Table 6, columns 1-3. In the subsample of SOE loans, PostIPO receives a statistically significant coefficient of -3.597 ; in the subsample of non-SOE loans, the same coefficient is - 1.417 , also statistically different from zero. The latter is notable as it indicates non-SOE borrowers are also subject to bank rent extraction in the pre-IPO period. This finding is intuitive because banks command holdup power against any borrowers as long as they possess proprietary information and/or the borrowers have limited alternative financing channels. In the full sample regression augmented with the SOE indicator variable and its interaction with PostIPO, PostIPO barely 
TA B LE 6 State ownership and loan rates around IPOs: Alternative samples

\begin{tabular}{|c|c|c|c|c|c|c|c|c|c|c|c|c|}
\hline & \multicolumn{3}{|c|}{1 year pre- and 1 year post-IPO } & \multicolumn{3}{|c|}{ Firms with one round of applications } & \multicolumn{3}{|c|}{$\begin{array}{l}\text { Pre- and post-IPO loans from the } \\
\text { same banks }\end{array}$} & \multicolumn{3}{|c|}{$\begin{array}{l}\text { Same-bank loans of firms with one } \\
\text { round of applications }\end{array}$} \\
\hline & $\begin{array}{l}\text { SOE } \\
\text { (1) }\end{array}$ & $\begin{array}{l}\text { Non-SOE } \\
\text { (2) }\end{array}$ & $\begin{array}{l}\text { All } \\
\text { (3) }\end{array}$ & $\begin{array}{l}\text { SOE } \\
\text { (4) }\end{array}$ & $\begin{array}{l}\text { Non-SOE } \\
\text { (5) }\end{array}$ & $\begin{array}{l}\text { All } \\
\text { (6) }\end{array}$ & $\begin{array}{l}\text { SOE } \\
\text { (7) }\end{array}$ & $\begin{array}{l}\text { Non-SOE } \\
\text { (8) }\end{array}$ & $\begin{array}{l}\text { All } \\
\text { (9) }\end{array}$ & $\begin{array}{l}\text { SOE } \\
(10)\end{array}$ & $\begin{array}{l}\text { Non-SOE } \\
\text { (11) }\end{array}$ & $\begin{array}{l}\text { All } \\
(12)\end{array}$ \\
\hline \multirow[t]{2}{*}{ PostIPO $_{i j t}$} & $-3.597^{* * *}$ & $-1.417^{* *}$ & $-1.594^{* * *}$ & $-4.812^{* * *}$ & -1.029 & $-1.328^{* *}$ & $-3.450^{* * *}$ & -0.917 & $-1.072^{*}$ & $-4.814^{* * *}$ & -0.853 & $-1.285^{*+}$ \\
\hline & $(-2.88)$ & $(-2.24)$ & $(-2.63)$ & $(-4.36)$ & $(-1.63)$ & $(-2.22)$ & $(-2.84)$ & $(-1.44)$ & $(-1.73)$ & $(-3.56)$ & $(-1.27)$ & $(-1.96)$ \\
\hline \multirow[t]{2}{*}{$\operatorname{SOE}_{i t}$} & & & -8.967 & & & $-3.911^{*}$ & & & -8.944 & & & -4.285 \\
\hline & & & $(-1.38)$ & & & $(-1.81)$ & & & $(-0.66)$ & & & $(-0.32)$ \\
\hline \multirow[t]{2}{*}{$S O E_{i t} \times P_{O S t} / P O_{i i j t}$} & & & $-0.972^{*}$ & & & $-2.642^{* * *}$ & & & $-1.602^{*}$ & & & $-2.589^{* *}$ \\
\hline & & & $(-1.91)$ & & & $(-2.70)$ & & & $(-1.85)$ & & & $(-2.34)$ \\
\hline $\begin{array}{l}\text { Loan } \\
\quad \text { characteristics }\end{array}$ & Yes & Yes & Yes & Yes & Yes & Yes & Yes & Yes & Yes & Yes & Yes & Yes \\
\hline $\begin{array}{l}\text { Firm } \\
\text { characteristics }\end{array}$ & Yes & Yes & Yes & Yes & Yes & Yes & Yes & Yes & Yes & Yes & Yes & Yes \\
\hline Bank relationships & Yes & Yes & Yes & Yes & Yes & Yes & Yes & Yes & Yes & Yes & Yes & Yes \\
\hline Time variables & Yes & Yes & Yes & Yes & Yes & Yes & Yes & Yes & Yes & Yes & Yes & Yes \\
\hline Constant & Yes & Yes & Yes & Yes & Yes & Yes & Yes & Yes & Yes & Yes & Yes & Yes \\
\hline Firm fixed effects & Yes & Yes & Yes & Yes & Yes & Yes & Yes & Yes & Yes & Yes & Yes & Yes \\
\hline Year fixed effects & Yes & Yes & Yes & Yes & Yes & Yes & Yes & Yes & Yes & Yes & Yes & Yes \\
\hline$N$ & 1,847 & 4,271 & 6,118 & 2,794 & 5,833 & 8,627 & 1,853 & 4,022 & 5,875 & 1,739 & 3,561 & 5,300 \\
\hline$R^{2}$ & 0.539 & 0.596 & 0.564 & 0.445 & 0.444 & 0.437 & 0.493 & 0.438 & 0.451 & 0.404 & 0.387 & 0.385 \\
\hline
\end{tabular}

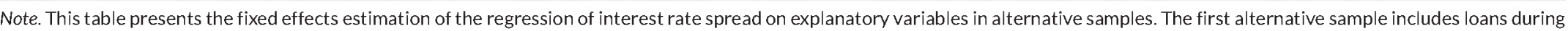



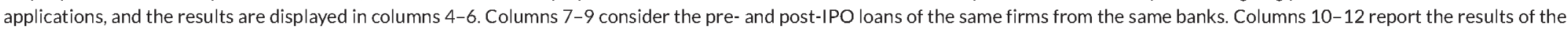

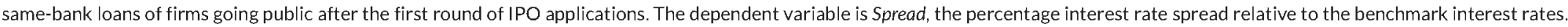
PostIPO is equal to $1 \mathrm{for}$ a loan taken after the firm's IPO. SOE is equal to $1 \mathrm{for}$ an SOE. $t$-Statistics are reported in parentheses.

****,**,* indicate statistical significance at the $.01, .05$ and .10 level, respectively. 
loads and the interaction term loads with a negative coefficient of -0.972 . Overall, these results are similar to those in Table 4 in that SOEs exhibit greater declines in interest rate around IPOs, consistent with our H1.

\section{Firms with one round of IPO applications}

Another way to refine our investigation is to focus on firms that go public after only one round of IPO applications. In China, firms file IPO applications with the China Securities Regulatory Commission (CSRC) for approval. In the application process, CSRC requires firms publish their prospectuses on the CSRC Web site as well as the designated newspapers (e.g., China Securities Daily). ${ }^{8} \mathrm{~A}$ firm has to go through the process again if its application is rejected by CSRC. In our sample, 37 firms went public after at least two rounds of applications. A vast amount of information has already been disclosed to the public long ahead of their IPOs, and including these firms would bias our results toward no interest rate decline around IPOs. ${ }^{\text {? }}$

Therefore, we exclude 1,069 loans of these 37 firms from our sample to rerun the baseline regressions. The results, presented in columns 4-6 of Table 6, are consistent and strong. PostIPO and SOE X PostIPO obtain coefficients that are notably larger and sometimes statistically more significant than in Table 5.

\section{Same-bank loans}

Our main sample includes all bank loans our sample firms have received during the [-3,3] period. These loans may come from a different set of banks pre-IPO from post-IPO. There are two benefits of considering loans from different banks: (1) the sample is significantly larger and better represents these firms' loan portfolios, and (2) it enables us to correctly construct banking relationship variables. A potential drawback, however, is that loans from different banks are less comparable. Thus, in yet another check, we restrict our sample to only loans that have counterpart loans from the same banks in the other period across the IPO event. To illustrate, assume firm A has a loan from bank $M$ and a loan from bank $N$ during the 3 years prior to its IPO, and a loan from bank $M$ during the 3 years post-IPO. Then only the two loans from bank $M$ will be kept, and the loan from bank $N$ drops out. This additional restriction ensures that we compare interest rates of the same bank-firm pairs during the pre- and post-IPO periods.

The estimation results, reported in Table 6, columns 7-9, are consistent with our expectation-that is, both PostIPO and SOE $\times$ PostIPO load negatively in column 9 . Their coefficients are statistically significant at only the $10 \%$ level due to the much smaller sample size; however, they are larger in magnitude than their counterparts in Table 5, reflecting a larger economic effect of IPO on loan interest rates.

We then further focus on firms with only one around of IPO applications and report the results in columns 10-12. The coefficients of PostIPO and SOE $\times$ POstIPO in column 12 are -1.285 and -2.589 , respectively, both larger than in column 9 , and statistically significant at the $5 \%$ level. Thus, when we examine only same-bank loans, we obtain qualitatively similar findings.

\subsection{2 | Matched-sample investigation}

Our detection of banks' rent extraction hinges on the IPO effects on the firms' information dissemination and financing channel expansion. A concern is that IPOs are not exogenous, and in particular, IPO decisions and the decline in loan interest rates may be driven by a same set of factors-for example, improved market conditions. If this is the case, then the decline in loan interest rates around IPOs cannot be interpreted as the evidence of pre-IPO rent extraction. Following Hale and Santos (2009), we employ the match sample approach to address this concern. The idea is that as the treatment sample (the listed firms) are similar to the control sample (the unlisted firms) in all characteristics but the IPO, the difference in interest rate patterns between the two matched samples is then attributable to the IPO event.

\footnotetext{
${ }^{8}$ The median (mean) length of the "information window" - that is, the period from the disclosure to IPO-is 121 (193) days during the 2012-2014 period, according to the Wind database. This time window was much narrower before 2012.

${ }^{9}$ In a similar vein, Hale and Santos (2009) document that the information effect of bond IPOs is larger for firms that get their first credit rating at the time of IPO than for those that have a rating prior to their IPOs, as prior credit rating would have carried a substantial amount of information.
} 
We restrict our investigation period to 1 year before and 1 year after the IPO date - that is, the $[-1,1]$ period - to enable the matched sample investigation. For a firm in our sample, the pool of candidate control firms includes all other firms at the time exactly 2 years ahead of their respective IPO years. Thus, for a pair of treatment firm and control firm, we have 2 years around the IPO for the treatment firm and 2 years for the control firm around a hypothetical IPO event occurring right at $t=-2$. To illustrate, firm A went public on May 31, 2010, and we have its loan information during June 1, 2007 to May 31, 2013. This firm on May 31, 2008 (its hypothetical IPO date as a control firm) then can be a control firm for treatment firm B that went public on, say, July 5, 2008. We will contrast firm A's interest rate spreads during June 1, 2007 to May 31, 2009, against those of firm B during July 5, 2007 to July 5, 2009-that is, the [-1, 1] period. The 1 year gap between firm A's hypothetical $[-1,1]$ period and its actual IPO date minimizes the possibility that IPO-related information dissemination has begun.

To find control firms, we first estimate the Probit model of having the equity IPO in any given year, using a set of firm characteristics as explanatory variables:

$$
P\left(I P O_{i t}\right)=\phi\left(\alpha+\beta X_{i t-1}\right)
$$

where $I P O_{i t}$ is an indicator that firm $i$ issued an IPO in year $t, X_{i t ~-1}$ is the vector of aforementioned firm characteristics, and $\Phi($.$) is the cumulative probability density function of the normal distribution. We use the estimated values of \alpha$ and $\beta$ to construct the propensity score for each firm $i$ in year $t$ as the predicted probability of an IPO.

Using this propensity score, we utilize radius matching (radius $=0.01$ ) to match IPO firms to candidates of control firms. We do not force each IPO firm to have a match; instead, we drop those IPO firms that do not have a close match. We also drop the non-IPO firms that are not used as a match for any IPO firm. Thus, our matched sample consists of only those firms that are similar in their probability of having an IPO. In the first attempt, we require that a non-IPO firm can be used as a control for one IPO firm (one-to-one matching), and obtain 67 pairs of IPO firms and control firms, with a total of 1,282 loans during the $[-1,1]$ periods. In another attempt, we allow a non-IPO firm to be controls for multiple IPO firms (one-to-N matching) and find 182 private firms to match 297 IPO firms combined having 3,045 loans. In either of the matched sample, we create a dummy variable, Treatment, that is equal to 1 for an IPO firm and 0 for a control firm.

We then rerun Equation (2) in the matched samples with the dummy Treatment, the interaction between PostIPO and Treatment, and the three-way interaction among SOE, PostIPO, and Treatment on the right-hand side. For a control firm, PostIPO is set to take the value 1 if the loan is taken in the second half of the 2 year period. The new regressions constitute difference-in-difference tests that can reliably expose the effect of IPO on loan rates as well as whether SOEs are victims of worse rent extraction.

Table 7 reports the regression results, with those based on the one-to-one matching in columns 1 and 2 and those based on the one-to- $\mathrm{N}$ matching in columns 3 and 4 . In columns 1 and 3 , the interaction term PostIPO $\times$ Treatment loads negatively, which tells that the interest rate spread declines only around the actual IPOs but not around the hypothetical IPOs, confirming the existence of holdup problem pre-IPO. The coefficient of Treatment is negative and statistically significant in columns 1 and 3 but not different from zero in columns 2 and 4 . This indicates that the IPO firms on average have lower interest rates than control firms, but the difference occurs in the post-IPO period. In columns 2 and 4 , the three-way interaction term SOE $\times$ POStIPO $\times$ Treatment also loads negatively, confirming our baseline finding in Table 5 that SOEs are subject to more severe bank rents in the pre-IPO period. ${ }^{10}$ Thus, controlling for the endogeneity of IPOs does not alter our results.

\footnotetext{
${ }^{10}$ Falsification tests we conduct verify that the parallel trends assumption holds for our difference-in-difference tests (e.g., Roberts $\&$ Whited, 2013). Specifically, we contrast loan interest rates of IPO firms in their $[-3,-1]$ period (relative to their actual IPO dates) against those of control firms in their $[-1,1]$ period (relative to their hypothetical IPO dates), and they are statistically equal. In regressions none of Treatment, PostIPO $\times$ Treatment, and $5 O E \times$ PostiPO $\times$ Treatment loads.
} 
TA B LE 7 State ownership and loan rates around IPOS: Matched sample estimation

\begin{tabular}{|c|c|c|c|c|}
\hline & \multicolumn{2}{|c|}{ One-to-one matching } & \multicolumn{2}{|c|}{ One-to- $\mathrm{N}$ matching } \\
\hline & (1) & (2) & (3) & (4) \\
\hline \multirow[t]{2}{*}{ PostlPO } & $2.184^{* *}$ & $3.736^{* *}$ & 0.548 & 1.777 \\
\hline & $(1.99)$ & $(2.47)$ & $(0.59)$ & $(1.52)$ \\
\hline \multirow[t]{2}{*}{ Treatment $_{i t}$} & $-27.533^{* *}$ & 3.288 & $-31.193^{* *}$ & -0.276 \\
\hline & $(-2.06)$ & $(0.18)$ & $(-2.07)$ & $(-0.02)$ \\
\hline \multirow[t]{2}{*}{ PostiPO $_{i j t} \times$ Treatment $_{i t}$} & $-4.024^{* * *}$ & $-5.122^{* * *}$ & $-0.249^{* *}$ & $-1.285^{*}$ \\
\hline & $(-3.62)$ & $(-3.30)$ & $(-2.24)$ & $(-1.82)$ \\
\hline \multirow[t]{2}{*}{$\mathrm{SOE}_{i t}$} & & $-2.179^{* *}$ & & $-2.603^{*}$ \\
\hline & & $(-2.08)$ & & $(-1.89)$ \\
\hline \multirow[t]{2}{*}{$S O E_{i t} \times P_{O S t} P_{i j t}$} & & 1.275 & & 1.186 \\
\hline & & $(0.60)$ & & $(0.55)$ \\
\hline \multirow[t]{2}{*}{$\mathrm{SOE}_{i t} \times$ PostIPO $_{i j t} \times$ Treatment $_{i t}$} & & $-3.065^{*}$ & & $-2.385^{*}$ \\
\hline & & $(-1.77)$ & & $(-1.80)$ \\
\hline \multirow[t]{2}{*}{ Maturity $_{j \mathrm{jt}}$} & $-0.499^{* * *}$ & $-0.512^{x * *}$ & $-0.616^{* * *}$ & $-0.628^{* * *}$ \\
\hline & $(-4.02)$ & $(-4.11)$ & $(-4.12)$ & $(-4.20)$ \\
\hline \multirow[t]{2}{*}{ Amount $t_{i j t}$} & $-0.949^{* *}$ & $-0.929^{* *}$ & $-0.805^{*}$ & $-0.784^{*}$ \\
\hline & $(-2.25)$ & $(-2.20)$ & $(-1.77)$ & $(-1.72)$ \\
\hline \multirow[t]{2}{*}{ Secured $_{i \mathrm{j}}$} & $3.716^{* *+}$ & $3.669^{*+*}$ & $2.745^{* * *}$ & $2.722^{* *+}$ \\
\hline & $(8.12)$ & $(8.00)$ & $(5.10)$ & $(5.05)$ \\
\hline \multirow[t]{2}{*}{$A g e_{i t-1}$} & $-0.939^{*}$ & $-0.941^{*}$ & -0.790 & -0.850 \\
\hline & $(-1.72)$ & $(-1.72)$ & $(-1.36)$ & $(-1.46)$ \\
\hline \multirow[t]{2}{*}{$S_{i z e} e_{i t-1}$} & $12.184^{* * *}$ & $11.958^{* * *}$ & $8.996^{* * *}$ & $9.294^{* * *}$ \\
\hline & $(5.64)$ & $(5.48)$ & (3.39) & $(3.50)$ \\
\hline \multirow[t]{2}{*}{$R O A_{i t-1}$} & -7.173 & -6.294 & $-13.500^{*}$ & $-13.327^{*}$ \\
\hline & $(-1.12)$ & $(-0.98)$ & $(-1.75)$ & $(-1.72)$ \\
\hline \multirow[t]{2}{*}{ Tangible $_{i t-1}$} & $-3.885^{*}$ & $-4.257^{* *}$ & -2.386 & -2.885 \\
\hline & $(-1.92)$ & $(-2.10)$ & $(-0.88)$ & $(-1.05)$ \\
\hline \multirow[t]{2}{*}{ Leverage $_{i t-1}$} & -2.223 & -2.012 & 5.161 & 5.155 \\
\hline & $(-0.98)$ & $(-0.88)$ & $(1.60)$ & $(1.60)$ \\
\hline \multirow[t]{2}{*}{ Earnings volatility } & 1.302 & 1.004 & 4.473 & 4.409 \\
\hline & $(1.27)$ & $(0.90)$ & $(1.55)$ & (1.14) \\
\hline \multirow[t]{2}{*}{ Loan concentration $_{\text {it }}$} & $-5.732^{* * *}$ & $-5.788^{x+1+}$ & $-7.831^{* * *}$ & $-7.808^{* * *}$ \\
\hline & $(-4.97)$ & $(-5.02)$ & $(-5.69)$ & $(-5.67)$ \\
\hline \multirow[t]{2}{*}{ Relationship intensity ${ }_{j \mathrm{jt}}$} & -0.345 & -0.325 & 0.625 & 0.600 \\
\hline & $(-0.60)$ & $(-0.56)$ & $(1.03)$ & $(0.98)$ \\
\hline \multirow[t]{2}{*}{ Recession $_{\mathrm{ijt}}$} & $4.919^{* * *}$ & $4.477^{*+*+}$ & $5.578^{* *}$ & $5.491^{* *}$ \\
\hline & $(3.63)$ & (3.25) & $(2.54)$ & $(2.44)$ \\
\hline Constant & Yes & Yes & Yes & Yes \\
\hline Firm fixed effects & Yes & Yes & Yes & Yes \\
\hline Year fixed effects & Yes & Yes & Yes & Yes \\
\hline
\end{tabular}




\begin{tabular}{|c|c|c|c|c|}
\hline & \multicolumn{2}{|c|}{ One-to-one matching } & \multicolumn{2}{|c|}{ One-to-N matching } \\
\hline & (1) & (2) & (3) & (4) \\
\hline$N$ & 1,282 & 1,282 & 3,045 & 3,045 \\
\hline$R^{2}$ & 0.565 & 0.578 & 0.532 & 0.538 \\
\hline
\end{tabular}

Note. This table presents the fixed effects estimation of the regression of interest rate spread on explanatory variables in the sample including IPO firms and their matched private firms. The private firms are identified using propensity score matching. Only loans made during 1 year before and 1 year after the IPO are included. Results based on one-to-one matching are displayed on the left, and those based on one-to- $N$ matching are on the right. The dependent variable is Spread, the percentage interest rate spread relative to the benchmark interest rates. PostIPO is equal to 1 for a loan taken after the firm's IPO. Treatment is equal to 1 for an IPO firm and zero for a match firm. SOE is equal to 1 for a firm whose ultimate controlling shareholder is the government. $t$-Statistics are reported in parentheses.

***,**** indicate statistical significance at the $.01, .05$ and .10 level, respectively.

\subsection{3 | Alternative interpretation: Change in ownership structure}

Besides holdup power of incumbent banks, the change in ownership structure of SOEs may give rise to the SOEs versus non-SOEs discrepancy in loan rate decline we have documented. As we discussed, SOEs pursue both financial and social goals. In an IPO, an SOE sells newly created and/or existing shares to new investors, including other state-owned institutions and corporations, privately owned institutional investors, and individual investors. If private investors gain greater influence on the SOE's business decisions, they will move its objective toward profit maximization. Increased profit maximization incentives then could drive managers to become more aggressive negotiators when dealing with banks, which in turn would lead to a drop in the loan interest rates. Non-SOEs, in contrast, are already profit maximizers before IPOs and probably will not experience a similar change in their incentives or interest rates.

To examine this alternative interpretation, we first tabulate the ownership structure of SOEs, pre- and post-IPO, in Table A3 in the Appendix. Our definition of SOE is based on the ultimate controller; therefore, we first check the change of ultimate owner around IPO in Panel A and then further investigate the changes of direct state ownership in Panel B. Only four out of 150 SOEs changed their ultimate controllers within 3 years after IPO. Yet, all the four new ultimate controllers are still governments. In other words, all SOEs remain state-owned post-IPO. Panel B reveals that out of all SOEs in our sample, 20 firms experienced a nonnegative change in state ownership around IPO, and the rest decreased their state ownership. State ownership declines by less than $20 \%$ for 36 firms, by more than $40 \%$ for 15 firms, and by an extent between $20 \%$ and $40 \%$ for 79 firms.

We then examine the interest rate declines around IPOs given various levels of change in state ownership and report the results in Table 8. First, we divide all SOEs into two groups: group 1 includes those that experienced an increase or minor decrease (less than 20\%) in state ownership around IPO, and group 2 includes those with a major decrease (over $20 \%$ ) in state ownership. If ownership structure change is the cause of interest rate declines, we would expect group 2 SOEs exhibit greater rate declines around IPO. Regressions of interest rate spread on PostIPO and all control variables, as shown in the first two columns of Table 8 , produce negative and statistically significant coefficients on PostIPO, indicating both groups of SOEs witness a decline in loan rates after IPO. Moreover, the coefficient for group $1(-4.083)$ is greater in magnitude than that for group $2(-3.253)$, inconsistent with the conjecture that ownership structure change matters. To further attack this issue, we run the Equation (2) regression in subsamples that include SOEs with a nonnegative change in state ownership and non-SOEs (column 3). The result is very similar to the baseline results reported in Table 5 . The coefficient of SOE $\times$ POStIPO is -5.209 , statistically significant at the $1 \%$ level, confirming that in absence of a decline of state ownership, SOEs on average experience a markedly larger decline in loan rate. In column 4, we exclude from the sample only those SOEs with a state ownership decline greater than $20 \%$, and the results are qualitatively similar. Thus, we can conclude that the consideration of ownership structure change does not alter our main findings - that is, greater pre-IPO information monopoly rents are behind the greater interest rate declines of SOEs after IPO. 
TA B LE 8 SOEs with or without major declines in state ownership after IPO

\begin{tabular}{|c|c|c|c|c|}
\hline & \multirow[b]{2}{*}{$\begin{array}{l}\text { SOEs with state } \\
\text { ownership } \\
\text { change }>-20 \%\end{array}$} & \multirow[b]{2}{*}{$\begin{array}{l}\text { SOEs with state } \\
\text { ownership } \\
\text { change }<-20 \%\end{array}$} & \multicolumn{2}{|c|}{ All firms except for } \\
\hline & & & $\begin{array}{l}\text { SOEs with state } \\
\text { ownership } \\
\text { change }<0\end{array}$ & $\begin{array}{l}\text { SOEs with state } \\
\text { ownership } \\
\text { change }<-20 \%\end{array}$ \\
\hline \multirow[t]{2}{*}{ Post $/ P_{i j t}$} & $-4.083^{* *}$ & $-3.253^{* *}$ & -0.857 & $-1.230^{* *}$ \\
\hline & $(-2.47)$ & $(-2.31)$ & $(-1.64)$ & $(-2.08)$ \\
\hline \multirow[t]{2}{*}{$\operatorname{SOE}_{i j t}$} & & & -5.779 & 15.296 \\
\hline & & & $(-0.35)$ & $(0.90)$ \\
\hline \multirow[t]{2}{*}{$S O E_{i j t} \times P_{0 s t I P O}$} & & & $-5.209^{* * *}$ & $-2.961^{* *}$ \\
\hline & & & $(-3.13)$ & $(-2.37)$ \\
\hline \multirow[t]{2}{*}{ Maturity $_{i j t}$} & $-0.472^{*}$ & $-1.550^{* * *}$ & $-1.121^{* * *}$ & $-0.922^{* * *}$ \\
\hline & $(-1.80)$ & $(-8.35)$ & $(-9.34)$ & $(-8.30)$ \\
\hline \multirow[t]{2}{*}{ Amount $_{i j t}$} & -1.484 & $-2.444^{* * *}$ & $0.852^{*}$ & 0.481 \\
\hline & $(-1.38)$ & $(-3.03)$ & (1.89) & (1.12) \\
\hline \multirow[t]{2}{*}{ Secured $_{i j t}$} & $8.617^{* * *}$ & $3.833^{* * *}$ & $3.273^{* * *}$ & $3.066^{* * *}$ \\
\hline & $(5.57)$ & (3.86) & (6.93) & $(6.60)$ \\
\hline \multirow[t]{2}{*}{$\mathrm{Age}_{i t-1}$} & 0.736 & $3.606^{* * *}$ & -0.790 & -0.648 \\
\hline & (0.71) & (3.26) & $(-1.57)$ & $(-1.41)$ \\
\hline \multirow[t]{2}{*}{$S_{i z e} e_{i t-1}$} & $24.413^{* * *}$ & -4.757 & 0.061 & $3.048^{*}$ \\
\hline & (3.92) & $(-0.80)$ & $(0.04)$ & $(1.95)$ \\
\hline \multirow[t]{2}{*}{$R^{\prime} O A_{i t-1}$} & -8.277 & $34.538^{*}$ & -3.176 & $-5.513^{*}$ \\
\hline & $(-0.48)$ & $(1.92)$ & $(-0.96)$ & $(-1.66)$ \\
\hline \multirow[t]{2}{*}{ Tangible $_{i t-1}$} & $-42.673^{* * *}$ & $7.005^{* *}$ & $6.446^{* *}$ & 1.319 \\
\hline & $(-5.25)$ & (2.09) & (2.39) & $(0.50)$ \\
\hline \multirow[t]{2}{*}{ Leverage $_{i t-1}$} & -6.502 & 6.644 & $5.651^{* *}$ & 3.039 \\
\hline & $(-0.81)$ & $(1.46)$ & $(2.04)$ & (1.13) \\
\hline \multirow[t]{2}{*}{ Earnings volatility } & 23.735 & 3.886 & 12.356 & $14.290^{*}$ \\
\hline & $(1.05)$ & $(0.16)$ & $(1.50)$ & $(1.84)$ \\
\hline \multirow[t]{2}{*}{ Loan concentration it $_{\text {it }}$} & -4.080 & 2.620 & 1.599 & 0.679 \\
\hline & $(-1.56)$ & $(1.41)$ & $(1.64)$ & $(0.72)$ \\
\hline \multirow[t]{2}{*}{ Relationship intensity $_{\mathrm{ijt}}$} & -0.007 & -1.529 & $1.213^{*}$ & 0.683 \\
\hline & $(-0.00)$ & $(-1.32)$ & $(1.82)$ & $(1.05)$ \\
\hline \multirow[t]{2}{*}{ Recession $_{i j t}$} & $12.601^{* * *}$ & $3.038^{* *}$ & 9.460 & $13.268^{* * *}$ \\
\hline & (3.06) & (2.10) & $(1.48)$ & $(4.07)$ \\
\hline Constant & Yes & Yes & Yes & Yes \\
\hline Firm fixed effects & Yes & Yes & Yes & Yes \\
\hline Loan year fixed effects & Yes & Yes & Yes & Yes \\
\hline$N$ & 1,163 & 1,949 & 7,003 & 7,707 \\
\hline$R^{2}$ & 0.480 & 0.437 & 0.478 & 0.459 \\
\hline
\end{tabular}

Note. This table presents the fixed effects estimation of the regression of interest rate spread on explanatory variables in subsamples of SOEs with or without a major decline $(<-20 \%)$ in state ownership after IPO, as well as in subsamples where SOEs experiencing declines or major declines in state ownership are excluded. The dependent variable is Spread, measured as a percentage difference in loan interest rate from the benchmark interest rates. PostIPO is equal to 1 when firm's loan is taken after the IPO. SOE is equal to 1 for a firm whose ultimate controlling shareholder is the government. $t$-Statistics are reported in parentheses.

***, **** indicate statistical significance at the $.01, .05$ and .10 level, respectively. 


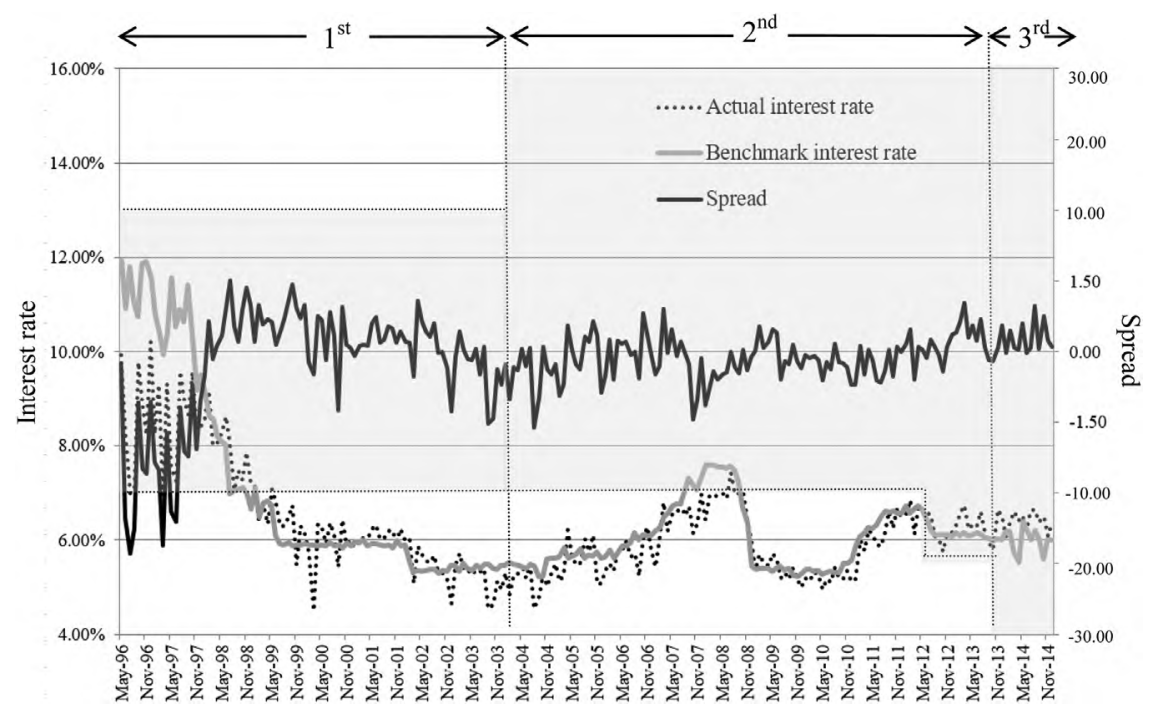

FIGURE 1 Loan interest rates and spreads over time in China's credit market

Note. The sample period is from May 1996 to December 2014. The vertical axis on the left is for the actual and the benchmark interest rates, and the vertical axis on the right is for the interest rate spread, measured as a percentage of the benchmark interest rate. Actual interest rate is averaged for all the loans in a month. Benchmark interest rate is averaged for all the base interest rates for loans with different maturities set by the People's Bank of China (PBOC) in a month. The gray area depicts the floating ranges of loan interest rates dictated by the PBOC.

\subsection{4 | Interest rate liberalization}

During our sample period, China's banking sector underwent gradual liberalization of interest rates, as depicted in Figure 1. The gray area represents the allowable interest rate range that expanded over time. The process exhibits two notable observations. First, actual interest rates of commercial banks (dotted line) closely track the official benchmark interest rates (gray line). Second, interest rate spread (solid line), the percentage gap between actual and benchmark interest rates, fluctuates around the average value of zero. There is not a discernable pattern of how the expansion in allowable interest rate range influences the interest rate spread.

Theoretically, the impact of interest rate liberalization on banks' rents is unclear as it provides incentives to both incumbent and outside banks to engage in information production. On the one hand, interest rate regulation restricts banks' rents involving information advantage, because deficient loan pricing ability impedes the complete compensation for cost of information production, which dampens incumbent banks' information production incentives. On the other hand, interest rate regulation is also a source of holdup power for incumbent banks (Salas \& Saurina, 2003), as rents can be partially or completely competed away via lower rates offered by outside lenders when interest rates is liberalized. Besanko and Thakor (1992) find that increased competition introduced by banking deregulation erodes rents associated with relationship banking.

Despite the ambiguous implication of interest rate liberalization on commercial banks' loan interest rates, we control for its potential impact by employing two dummy variables, Liberalization I and Liberalization II, to capture the two major steps in the process of China's interest rate liberalization process. Regression results are in Table 9, columns 1 and 2 . The two liberalization indicators obtain positive but statistically insignificant coefficients in either specification. Our variable of interest is still the interaction term SOE $\times$ PostIPO, which receives a negative and statistically significant coefficient in column 2 , indicating that after controlling of interest rate liberalization, SOEs still experience more pronounced interest rate cuts after their IPOs. Thus, the interest rate liberalization does not undercut our finding that interest rate decline around IPOs is the result of dissolving information monopoly. 
TA B LE 9 Controlling for interest rate liberalization and information asymmetry

\begin{tabular}{|c|c|c|c|c|}
\hline & (1) & (2) & (3) & (4) \\
\hline \multirow[t]{2}{*}{ Post $\mathrm{PO}_{i j \mathrm{t}}$} & $-1.472^{* * *}$ & $-1.037^{*}$ & $-1.701^{* * *}$ & $-1.371^{* x}$ \\
\hline & $(-2.90)$ & $(-1.82)$ & $(-3.17)$ & $(-2.31)$ \\
\hline \multirow[t]{2}{*}{$S O E_{i j t}$} & & -18.603 & & -10.005 \\
\hline & & $(-1.34)$ & & $(-0.95)$ \\
\hline \multirow[t]{2}{*}{ 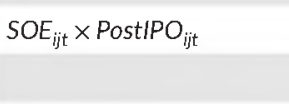 } & & $-1.547^{* *}$ & & $-1.287^{*}$ \\
\hline & & $(-1.97)$ & & $(-1.69)$ \\
\hline \multirow[t]{2}{*}{ Liberalization $I_{i j t}$} & 2.281 & 2.254 & & \\
\hline & $(1.23)$ & $(1.21)$ & & \\
\hline \multirow[t]{2}{*}{ Liberalization $\|_{i j \mathrm{t}}$} & 0.158 & 0.166 & & \\
\hline & $(0.07)$ & $(0.07)$ & & \\
\hline \multirow[t]{2}{*}{ Underwriter_reputation $_{i j t}$} & & & 0.325 & 1.272 \\
\hline & & & $(0.42)$ & (1.14) \\
\hline \multirow[t]{2}{*}{ Analyst_coverage $_{i j t}$} & & & -0.659 & -2.414 \\
\hline & & & $(-0.12)$ & $(-0.42)$ \\
\hline \multirow[t]{2}{*}{ Disclosure violation } & & & $18.438^{*}$ & $13.946^{*}$ \\
\hline & & & (1.88) & $(1.71)$ \\
\hline \multirow[t]{2}{*}{ Earnings quality $_{i j t}$} & & & 30.301 & 28.492 \\
\hline & & & (1.14) & $(1.04)$ \\
\hline \multirow[t]{2}{*}{ Maturity $_{i j t}$} & $-1.080^{* n+x}$ & $-1.088^{* * * x}$ & $-0.830^{* * * *}$ & $-0.838^{* * *}$ \\
\hline & $(-11.41)$ & $(-11.49)$ & $(-8.13)$ & $(-8.19)$ \\
\hline \multirow[t]{2}{*}{ Amount $t_{i j t}$} & -0.232 & -0.205 & -0.468 & -0.442 \\
\hline & $(-0.61)$ & $(-0.54)$ & $(-1.15)$ & $(-1.08)$ \\
\hline \multirow[t]{2}{*}{ Secured $_{i j \mathrm{t}}$} & $3.097^{* * *}$ & $3.075^{* * *+}$ & $3.577^{*+*+}$ & $3.551^{* *+*}$ \\
\hline & $(7.40)$ & (7.34) & $(8.17)$ & (8.11) \\
\hline \multirow[t]{2}{*}{$\mathrm{Age}_{i t-1}$} & -0.173 & -0.160 & -0.162 & -0.149 \\
\hline & $(-0.40)$ & $(-0.37)$ & $(-0.35)$ & $(-0.33)$ \\
\hline \multirow[t]{2}{*}{ Size $_{i t-1}$} & $3.397^{* *}$ & $3.017^{* *}$ & $4.570^{* * * *}$ & $4.275^{* * *}$ \\
\hline & (2.33) & (2.04) & (3.02) & $(2.79)$ \\
\hline \multirow[t]{2}{*}{$R O A_{\text {it }-1}$} & -4.840 & -4.285 & -3.197 & -2.778 \\
\hline & $(-1.51)$ & $(-1.33)$ & $(-0.99)$ & $(-0.85)$ \\
\hline \multirow[t]{2}{*}{ Tangible $_{i t-1}$} & $4.251^{* *}$ & $4.051^{* *}$ & 1.328 & 1.205 \\
\hline & (2.28) & (2.17) & $(0.68)$ & $(0.62)$ \\
\hline \multirow[t]{2}{*}{ Leverage $_{\text {it }-1}$} & $5.530^{* * x}$ & $5.706^{* * *}$ & 2.311 & 2.482 \\
\hline & $(2.80)$ & (2.88) & (1.12) & $(1.20)$ \\
\hline \multirow[t]{2}{*}{ Earnings volatility } & $1.101^{* *}$ & $1.294^{*}$ & $12.344^{*}$ & 11.617 \\
\hline & $(2.07)$ & (1.96) & $(1.69)$ & (1.58) \\
\hline \multirow[t]{2}{*}{ Loan_concentration $_{\text {it }}$} & $1.482^{*}$ & 1.358 & 0.313 & 0.214 \\
\hline & $(1.79)$ & $(1.63)$ & $(0.36)$ & $(0.24)$ \\
\hline \multirow[t]{2}{*}{ Relationship intensity ${ }_{j \mathrm{jt}}$} & -0.006 & 0.012 & 0.357 & 0.384 \\
\hline & $(-0.01)$ & $(0.02)$ & $(0.58)$ & $(0.62)$ \\
\hline Recession $_{i j \mathrm{t}}$ & $4.975^{* * *}$ & $4.668^{* * *}$ & $3.451^{*}$ & $3.061^{*}$ \\
\hline
\end{tabular}


TABLE 9 (Continued)

\begin{tabular}{|c|c|c|c|c|}
\hline & (1) & (2) & (3) & (4) \\
\hline & $(3.74)$ & (3.47) & (1.95) & $(1.70)$ \\
\hline Constant & Yes & Yes & Yes & Yes \\
\hline Firm fixed effects & Yes & Yes & Yes & Yes \\
\hline Loan year fixed effects & Yes & Yes & Yes & Yes \\
\hline$N$ & 9,656 & 9,656 & 8,133 & 8,133 \\
\hline$R^{2}$ & 0.450 & 0.450 & 0.388 & 0.388 \\
\hline
\end{tabular}

Note. The dependent variable is the interest rate spread. PostIPO is equal to 1 for a loan taken after the firm's IPO. SOE is equal to 1 for a firm whose ultimate controlling shareholder is a local or central government. Liberalization I (Liberalization II) is equal to 1 for a loan is taken from October 29, 2004 to July 19, 2013 (after July 20, 2013). Underwriter reputation is measured by the market share of the lead underwriters; Analyst coverage is the log of 1 plus the firm's average number of financial analysts following the firm after its IPO; Disclosure violation is equal to 1 when a firm is criticized for or charged with information disclosure regulations violations by the stock exchange or the CSRC after IPO. Earnings quality is measured by abnormal accruals. t-Statistics are reported in parentheses.

***,**** indicate statistical significance at the $.01, .05$ and .10 level, respectively.

\subsection{5 | Controlling for information asymmetry}

In this study, we interpret the decline in loan interest rates around IPOs as the result of vanishing holdup power of banks. An implicit assumption is in place for us to compare bank rents across SEOs versus non-SEOs: A bank's holdup power, if any, completely vanishes after the borrower's IPO. We acknowledge whether this assumption holds is debatable as stock market evidence shows varying levels of information asymmetry exist on publicly listed companies. PostIPO information asymmetry would limit the firm's ability to further resort to equity financing and hence erode banks' holdup power (Myers \& Majluf, 1984). The decline in loan interest rate thus captures only a fraction of banks' holdup power that is eliminated around IPO.

To mitigate this concern, we control for firms' information asymmetry using four variables: Underwriter reputation, Analyst coverage, Disclosure violation, and Earnings quality. In the book-building procedure that prevails in China's IPO market, investment banks acquire information about the issuer quality through due diligence as well as from informed investors (e.g., Benveniste \& Spindt, 1989; Hanley, 1993), and more reputable underwriters produce more information than less reputable ones (Wang \& Yung, 2011). We measure a borrower's IPO underwriter reputation using the market share of the lead underwriter during the IPO year (e.g., Megginson \& Weiss, 1990). Analysts are important information producers (e.g., Frankel \& Li, 2004; Hong, Lim, \& Stein, 2000), and we construct the variable as the log of 1 plus the average number of analysts following a firm. Besides, post-IPO information asymmetry depends on the quality of information disclosure by the publicly listed companies themselves, as low disclosure quality creates uncertainty about, among others, the credibility of financial statements (Graham, Li, \& Qiu, 2008). We measure information disclosure quality by the following two variables. Disclosure violation is a dummy variable that is equal to 1 if a firm is criticized for or charged with violations of information disclosure regulations by the stock exchange where its stocks trade, or the CSRC in the $[-3,3]$ event window. Earnings quality is measured as the change in total accruals from the previous year (e.g., DeAngelo, 1986).

We rerun the regressions in a smaller sample where the values of these four variables are available. Table 9 , columns 3 and 4 report the results. While Underwriter reputation, Analyst coverage, and Earnings quality do not load, Disclosure violation obtains a positive and statistically significant coefficient. Nevertheless, they do not alter our main results. PostIPO and SOE $\times$ PostIPO both load negatively. Thus, after controlling for residual information asymmetry, SOEs still benefit more from mitigation of banks' holdup power.

\subsubsection{Additional robustness checks}

Our main variable of interest, interest rate spread, is computed relative to the benchmark interest rates set by the PBOC. As the PBOC may have incentives to use the benchmark rates for macro-control purposes, they may not 
TA B L E 10 Loan rates of the Big Four versus other banks

\begin{tabular}{llccccc|}
\hline & & Whole period & Pre-IPO & Post-IPO & Difference & t-Statistic \\
\hline All loans & Big Four & 0.293 & 0.656 & -0.165 & $-0.821^{* *}$ & -2.159 \\
\multirow{2}{*}{ SOE loans } & Non-Big Four & -0.719 & 1.610 & -2.774 & $-4.384^{* * *}$ & -7.089 \\
& Big Four & -0.021 & 1.450 & -2.597 & $-4.047^{* * *}$ & -5.738 \\
\multirow{2}{*}{ Non-SOE loans } & Non-Big Four & -1.937 & 0.061 & -4.285 & $-4.346^{* * *}$ & -3.750 \\
& Big Four & 0.519 & -0.068 & 1.111 & $1.179^{* * *}$ & 2.774 \\
& Non-Big Four & -0.333 & 2.203 & -2.377 & $-4.581^{* * *}$ & -6.281 \\
\hline
\end{tabular}

Note. This table compares the changes in loan interest rate spread around borrower IPOs for loans made by the Big Four banks and non-Big Four banks in the full sample, as well as in the subsamples of SOE loans and non-SOE loans. The Big Four refers to the four largest commercial banks in China controlled by the central government. Spread is measured as a percentage spread relative to the benchmark interest rates set by the PBOC. In each sample, the difference in the mean pre-IPO spread and postIPO spread is reported and tested using a t-test.

******* indicate statistical significance at the $.01, .05$ and .10 level, respectively.

perfectly reflect the macroeconomic expectations. Thus, in addition to Recession, we bring in two sets of variables to refine our control of macroeconomic expectations: the actual growth rates in money supply $M 2$, consumer price index, and gross domestic product, respectively, in the previous year; and the average expectation of growth rates of these metrics from the survey of economists (Gilbert, 2011). The former data are from the Wind database, while the latter are from the Bloomberg database. Controlling for these variables does not alter our main results.

In yet another attempt, we reestimate our baseline regressions considering firm and year two-way clustered errors (Cameron, Gelbach, \& Miller, 2011). The coefficients of interest are still statistically significant, albeit at lower levels, ${ }^{11}$ consistent with our $\mathrm{H} 1$. Tables reporting these additional robustness checks are available on request.

\subsection{The Big Four banks and information rents}

We then proceed to investigate whether the Big Four banks behave differently from other banks in exploiting holdup power they may possess $(\mathrm{H} 2)$. Univariate comparisons are presented in Table 10. In the full sample, loans made by the Big Four charge a slightly lower spread (0.821 percentage points) after the borrower IPOs, while non-Big Four banks lower their loan spreads by a much larger discount of 4.384 percentage points. In the subsample of SOE loans, the Big Four and non-Big Four banks both witness a decline in interest rate spread of about 4 percentage points. When the borrowers are non-SOE firms, a stark contrast arises: the Big Four banks' percentage loan spreads on average increase by 1.179 percentage points, ${ }^{12}$ while those for other banks decline by 4.581 percentage points. These comparisons seem to suggest that the Big Four enjoy lower information rents, especially when they lend to non-SOE firms.

Table 11 reports multivariate analyses. In column 1, we run a regression that has Big4, the indicator of a loan from a Big Four bank, and its interaction with PostIPO as additional independent variables. PostIPO and Big4 both load negatively, and their interaction term obtains a positive coefficient of 1.802 that is statistically significant at the $1 \%$ level. This shows overall loan rate declines after IPO, the Big Four banks charge lower rates, and the loan rate decline around IPO is significantly smaller for the Big Four, consistent with our hypothesis. Assuming a benchmark rate of $6 \%$, the Big Four's rate decline is 13 basis points smaller than non-Big Four's.

In column 2, we add the SOE indicator, its interaction with PostIPO, and the three-way interaction SOE $\times$ Big4 $\times$ PostIPO to the right-hand side of the regression. The aforementioned results do not change qualitatively: PostIPO and

\footnotetext{
11 Cameron et al. (2011) and Thompson (2011) show that two-way clustering may not be suitable for data sets where $N$ and T are very different. Our data set has 495 firms observed over 19 -year periods.

12 The apparent increase of spreads for non-SOE loans from the Big Four banks is the result of changing firm composition pre- versus post-IPO. Out of all non-SOEs borrowing from the Big Four pre-IPO, 59 (or 25.2\%) non-SOEs did not initiate new loans from them during the 3-year post-IPO period. In addition, 49 (20.9\%) non-SOEs that did not have loans from the Big Four borrowed from them in the post-IPO period. After controlling for loan, firm, and banking relationship variables, interest rate declines after IPO for loans from the Big Four banks to non-SOE borrowers, as discussed later in the section.
} 
TA B LE 11 Big Four banks and loan rates around IPOS

\begin{tabular}{|c|c|c|c|c|c|c|c|c|c|}
\hline & \multirow[b]{2}{*}{ All } & \multirow[b]{2}{*}{ All } & \multirow[b]{2}{*}[-1,1]{} & \multirow[b]{2}{*}{$\begin{array}{l}\text { Firms with one } \\
\text { round of } \\
\text { applications }\end{array}$} & \multirow[b]{2}{*}{$\begin{array}{l}\text { Same-bank } \\
\text { loans }\end{array}$} & \multicolumn{2}{|c|}{ All firms except for } & \multirow{3}{*}{$\begin{array}{l}\text { All } \\
\text { (8) }\end{array}$} & \multirow{3}{*}{$\begin{array}{l}\text { All } \\
\text { (9) }\end{array}$} \\
\hline & & & & & & $\begin{array}{l}\text { SOEs with state } \\
\text { ownership } \\
\text { change }<0\end{array}$ & $\begin{array}{l}\text { SOEs with state } \\
\text { ownership } \\
\text { change }<-20 \%\end{array}$ & & \\
\hline & (1) & (2) & (3) & (4) & (5) & (6) & (7) & & \\
\hline \multirow[t]{2}{*}{ PostIPO $_{i j t}$} & $-2.685^{* * *}$ & $-2.563^{* * *}$ & -1.605 & $-1.571^{* *}$ & $-1.628^{* *}$ & $-2.916^{* * *}$ & $-3.055^{* * *}$ & $-2.632^{* * *}$ & $-3.222^{* * * x}$ \\
\hline & $(-4.27)$ & $(-3.73)$ & $(-1.47)$ & $(-2.19)$ & $(-2.00)$ & $(-4.07)$ & $(-4.28)$ & $(-3.82)$ & $(-4.49)$ \\
\hline \multirow[t]{2}{*}{$B i g 4_{i j t}$} & $-1.253^{* * *}$ & $-1.374^{* * *}$ & $-1.606^{* * *}$ & $-1.188^{*+}$ & $-1.183^{*}$ & $-2.303^{* * *}$ & $-1.939^{* * *}$ & $-1.362^{* * *}$ & $-2.123^{* * *}$ \\
\hline & $(-2.68)$ & $(-2.95)$ & $(-2.93)$ & $(-2.43)$ & $(-1.73)$ & $(-4.42)$ & $(-3.78)$ & $(-2.92)$ & $(-4.13)$ \\
\hline \multirow[t]{2}{*}{ Big4 $_{i j t} \times$ PostIPO $_{i j t}$} & $1.802^{* * *}$ & $2.773^{* * *}$ & 0.497 & $2.075^{* * *}$ & $0.955^{*}$ & $3.533^{* * *}$ & $3.167^{* * *}$ & $2.780^{* * *}$ & $3.249^{* * *}$ \\
\hline & $(2.94)$ & (4.19) & $(1.58)$ & (2.99) & $(1.77)$ & $(5.13)$ & $(5.57)$ & $(4.20)$ & $(4.66)$ \\
\hline \multirow[t]{2}{*}{$\mathrm{SOE}_{i j \mathrm{t}}$} & & -18.045 & $29.124^{*}$ & -3.885 & -8.134 & 7.601 & 14.773 & -18.166 & -9.884 \\
\hline & & $(-1.30)$ & $(1.80)$ & $(-0.29)$ & $(-0.60)$ & $(0.44)$ & $(0.87)$ & $(-1.31)$ & $(-0.94)$ \\
\hline \multirow[t]{2}{*}{$S O E_{i j t} \times P_{0 s t} P_{i j t}$} & & 0.275 & -1.903 & 0.954 & -2.182 & -3.205 & 0.309 & 0.286 & 0.259 \\
\hline & & $(0.24)$ & $(-1.05)$ & $(0.78)$ & $(-1.41)$ & $(-1.52)$ & $(0.21)$ & $(0.25)$ & $(0.21)$ \\
\hline \multirow{2}{*}{$\begin{array}{c}\text { SOE } \times B_{i g} 4_{i j t} \times \\
\text { PostIPO }_{i j \mathrm{i}}\end{array}$} & & $-3.195^{* * *}$ & $-1.010^{*}$ & $-2.649^{* *}$ & -0.462 & $-2.618^{* *}$ & $-5.551^{* * *}$ & $-3.171^{* * *}$ & $-2.849^{* * *}$ \\
\hline & & $(-3.00)$ & $(-1.67)$ & $(-2.36)$ & $(-1.31)$ & $(-2.21)$ & $(-4.07)$ & $(-2.98)$ & $(-2.59)$ \\
\hline $\begin{array}{l}\text { Loan, firm, bank } \\
\text { relationship, and } \\
\text { time variables }\end{array}$ & Yes & Yes & Yes & Yes & Yes & Yes & Yes & Yes & Yes \\
\hline Liberalization dummies & No & No & No & No & No & No & No & Yes & No \\
\hline $\begin{array}{l}\text { Info asymmetry } \\
\text { variables }\end{array}$ & No & No & No & No & No & No & No & No & Yes \\
\hline Constant & Yes & Yes & Yes & Yes & Yes & Yes & Yes & Yes & Yes \\
\hline
\end{tabular}


TABLE 11 (Continued)

\begin{tabular}{|c|c|c|c|c|c|c|c|c|c|}
\hline & \multirow[b]{2}{*}{ All } & \multirow[b]{2}{*}{ All } & \multirow[b]{2}{*}[-1,1]{} & \multirow[b]{2}{*}{$\begin{array}{l}\text { Firms with } \\
\text { one round of } \\
\text { applications }\end{array}$} & \multirow[b]{2}{*}{$\begin{array}{l}\text { Same-bank } \\
\text { loans }\end{array}$} & \multicolumn{2}{|c|}{ All firms except for } & \multirow[b]{2}{*}{ All } & \multirow[b]{2}{*}{ All } \\
\hline & & & & & & $\begin{array}{l}\text { SOEs with state } \\
\text { ownership } \\
\text { change }<0\end{array}$ & $\begin{array}{l}\text { SOEs with state } \\
\text { ownership } \\
\text { change }<-20 \%\end{array}$ & & \\
\hline & (1) & (2) & (3) & (4) & (5) & (6) & (7) & (8) & (9) \\
\hline Firm fixed effects & Yes & Yes & Yes & Yes & Yes & Yes & Yes & Yes & Yes \\
\hline $\begin{array}{l}\text { Loan year fixed } \\
\text { effects }\end{array}$ & Yes & Yes & Yes & Yes & Yes & Yes & Yes & Yes & Yes \\
\hline$N$ & 9,656 & 9,610 & 4,612 & 8,760 & 5,875 & 6,984 & 7,664 & 9,610 & 8,097 \\
\hline$R^{2}$ & 0.450 & 0.452 & 0.565 & 0.416 & 0.452 & 0.480 & 0.462 & 0.452 & 0.392 \\
\hline
\end{tabular}

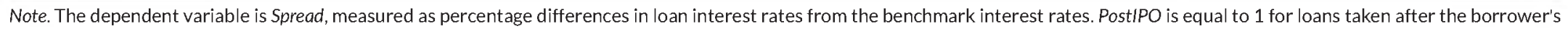

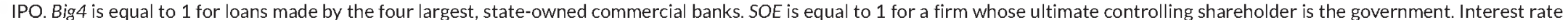


variables are controlled for in all models. $t$-Statistics are reported in parentheses.

******** indicate statistical significance at the $.01, .05$ and .10 level, respectively. 
Big4 load negatively and Big4 $\times$ PostJPO loads positively. SOE $\times$ PostIPO obtains a coefficient that is not significantly different from zero, but SOE $\times$ Big $4 \times$ PostIPO receives a coefficient of -3.195 , statistically significant at the $1 \%$ level. Thus, the greater bank rents SOEs suffer from are mainly from loans from the Big Four banks. Moreover, despite their overall lower rent extraction, the Big Four enjoy greater rents from SOEs. This indicates that SOEs' greater information asymmetry outweighs the common objectives between state-owned firms and banks to provide the Big Four greater holdup power.

Untabulated results show that the sum of the coefficients of PostIPO, Big4, and Big $4 \times$ PostIPO is -1.164 , statistically significant at the $1 \%$ level. Thus, when non-SOE firms borrow from the Big Four banks, the holdup problem still exists but is much less severe.

Columns 3-9 present robustness check results. We run the column 2 regression in alternative samples, considering state-ownership changes, and controlling for interest rate liberalization and post-IPO information asymmetry, and find qualitatively similar results in all attempts. Thus, consistent with our hypothesis, the Big Four banks appear to extract lower rents from holding up borrower firms. This is true especially when the borrowers are non-SOEs.

\subsection{Discussion: Alternative interpretations of loan rate declines around IPO}

Loan interest rates may go lower post-IPO as the result of a decline in perceived risk of issuer firms. Pagano et al. (1998) and Hsu et al. (2010) point out that equity issuance lowers the issuer's debt ratio, enhances its ability to service existing debt, as well as raises its debt capacity. The reduced financial risk, in turn, leads to lower cost of debt. This effect would cause a similar decline in interest rates around IPO as the mitigation of banks' holdup power. In all our prior investigations, we control for borrower firms' financial risk using its debt-to-asset ratios and earnings volatility both before and after their IPOs. These two variables load positively, consistent with the positive relationship between financial risk and cost of credit. Untabulated comparisons show that our sample firms on average exhibit a drop in both debt ratios and earnings volatility post-IPO, indicating post-IPO firms do have reduced financial risk. However, these variables fail to subsume our mitigation of bank rents interpretation of the main results.

Underwriter reputation could exert a certification effect (e.g., Carter \& Manaster, 1990), and analyst coverage following IPOs would lead to improved investor recognition. One can argue that both may positively contribute to IPO firms' future cash flows and give rise to lower interest rates. The results in Table 9 show that our findings about bank rents remain intact in the presence of underwriter reputation and analyst coverage.

\section{5 | CONCLUSION}

In this paper, we empirically investigate how Chinese banks exploit their information advantage to extract rents. Theories suggest that information asymmetry among banks, coupled with a firm's limited nonbank financing options, enables an incumbent bank to hold up the borrower for higher interest rates. Since an equity IPO disseminates a large amount of information as well as expands financing channels for a borrower firm, it erodes the incumbent bank's holdup power and forces it to cut loan interest rates after the borrower's IPO. The decline in loan interest rates around a firm's IPO hence indicates the existence of rent extraction by the banks prior to the IPO.

As governments own some of borrower firms as well as some of the banks, China's credit market provides a unique laboratory to examine how state ownership influences the cost of credit. We argue that SOEs suffer from worse information asymmetry, stemming from the separation of ownership (the public) and control (politicians) and the dualobjective problem (both financial and social objectives). As a result, they often face higher switching costs in the credit market and pay higher rents to their lenders. The state-owned Big Four banks, subject to similar problems as SOEs, place less emphasis on information production in the lending process and hence would enjoy lower rents than their smaller, privately owned peers.

Using a large proprietary sample of bank loan contracts in China spanning the period from 1996 to 2014, we find that loan interest rate spreads (relative to the benchmark rate set by the central bank) decline after firms undertake 
their IPOs. This indicates that Chinese banks overall do hold up borrowers to extract rents, despite their lack of pricing capacity during most of our sample period. SOEs experience significantly larger declines in loan interest rates around their IPOs than non-SOE borrowers. The Big Four banks cut their loan rates by a smaller percentage than non-Big Four banks after the borrowers go public, and the Big Four's rate cuts concentrate on loans made to SOEs. All these results are consistent with our expectations and robust to a wide array of robustness checks.

Our paper represents the first attempt to understand the lending relationships confounded by government ownerships. It extends the existing literature of banking relationships by providing an institutional angle to view the variation in banks' holdup power. Our findings reveal yet another implication of state ownership in business management. While promoting social welfare, state ownership undercuts the efficiency of both parties in the credit market in that it increases the cost of debt for borrowers and weakens banks' incentives for efficient credit allocation.

\section{ACKNOWLEDGMENTS}

The authors are grateful to the Editor (Richard Warr), anonymous reviewers, Kelly Cai, and Chung-Hua Shen for their valuable suggestions and advice. The authors also thank session participants at the 2017 Southern Financial Association (SFA) annual meeting, the 2013 Midwest Financial Association (MFA) annual meeting, the 2013 Eastern Financial Association (EFA) annual meeting, and the 9th China Finance Annual Meeting for helpful comments. An author also owes her debt to the scholarship from China Scholarship Council (File No. 201606255085). Research support is provided by the National Natural Science Foundation of China (Grant No. 71872127; 71403183; 71790594).

\section{REFERENCES}

Allen, F. (1990). The market for information and the origin of financial intermediation. Journal of Financial Intermediation, 1 , 3-30.

Bai, C., Lu, J., \& Tao, Z. (2006). The multitask theory of state enterprise reform: Empirical evidence from China. American Economic Review, 96, 353-357.

Barth, J. R., Caprio, G., \& Levine, R. (2004). Bank regulation and supervision: What works best? Journal of Financial Intermediation, $13,205-248$.

Baumol, W. J. (1984). Towards a theory of public enterprise. Atlantic Economic Journal, 12, 13-19.

Benveniste, L., \& Spindt, P. (1989). How investment banks determine the offer price and allocation of new issues. Journal of Financial Economics, 24, 343-362.

Berger, A. N., Hasan, I., \& Zhou, M. (2009). Bank ownership and efficiency in China: What will happen in the world's largest nation? Journal of Banking and Finance, 33, 113-130.

Berger, A. N., \& Udell, G. F. (1990). Collateral, loan quality and bank risk. Journal of Monetary Economics, 25, 21-42.

Besanko, D., \& Thakor, A. V. (1992). Banking deregulation: Allocational consequences of relaxing entry barriers. Journal of Banking and Finance, 16, 909-932.

Bharath, S. T., Dahiva, S., Saunders, A., \& Srinivasan, A. (2011). Lending relationships and loan contract terms. Review of Financial Studies, 24, 1141-1203.

Boubakri, N., Cosset, J.-C., \& Saffar, W. (2013). The role of state and foreign owners in corporate risk-taking: Evidence from privatization. Journal of Financial Economics, 2, 641-658.

Bushman, R. M., Piotroski, J. D., \& Smith, A. J. (2004). What determines corporate transparency? Journal of Accounting Research, $42,207-252$.

Cameron, A. C., Gelbach, J. B., \& Miller, D. L. (2011). Robust inference with multiway clustering. Journal of Business and Economic Statistics, 29, 238-249.

Carter, R., \& Manaster, S. (1990). Initial public offerings and underwriter reputation. Journal of Finance, 45, 1045-1067.

Chang, C., Liao, G., Yu, X., \& Ni, Z. (2014). Information from relationship lending: Evidence from loan defaults in China. Journal of Money, Credit and Banking, 46, 1225-1257.

Chen, J., Lobo, G., Wang, Y., \& Yu, L. (2013). Loan collateral and financial reporting conservatism: Chinese evidence. Journal of Banking and Finance, 37, 4989-5006.

Cull, R., \& Xu, L. C. (2003). Who gets credit? The behavior of bureaucrats and state banks in allocating credit to Chinese stateowned enterprises. Journal of Development Economics, 71, 533-559. 
De Alessi, L. (1974). Managerial tenure under private and government ownership in the electric power industry. Journal of Political Economy, 82(3), 645-653.

Deangelo, L. E. (1986). Accounting numbers as market valuation substitutes: A study of management buyouts of public stockholders. The Accounting Review, 61, 400-420.

Degryse, H., \& Van Cayseele, P. (2000). Relationship lending within a bank-based system: Evidence from European small business data. Journal of Financial Intermediation, 9, 90-109.

Diamond, D. (1984). Financial intermediation and delegated monitoring. Review of Economic Studies, 51, 393-414.

Ferri, G. (2009). Are new tigers supplanting old mammoths in China's banking system? Evidence from a sample of city commercial banks. Journal of Banking and Finance, 33, 131-140.

Frankel, R., \& Li, X. (2004). Characteristics of a firm's information environment and the information asymmetry between insiders and outsiders. Journal of Accounting and Economics, 37, 229-259.

Gao, H., Wang, J., Yang, X., \& Zhao, L. (2017). Who borrow more from "deep-pocket" banks theory and evidence from China. Unpublished Working paper. Chinese Academy of Sciences, Beijing, China.

Gilbert, T. (2011). Information aggregation around macroeconomic announcements: Revisions matter. Journal of Financial Economics, 101, 114-131.

Graham, J., Li, S., \& Qiu, J. (2008). Corporate misreporting and bank loan contracting. Journal of Financial Economics, 89, 44-61.

Guedhami, O., Pittman, J. A., \& Saffar, W. (2009). Auditor choice in privatized firms: Empirical evidence on the role of state and foreign owners. Journal of Accounting and Economics, 48, 151-157.

Hale, G., \& Santos, J. A. (2009). Do banks price their informational monopoly? Journal of Financial Economics, 93, $185-206$.

Hanley, K. (1993). The underpricing of initial public offerings and the partial adjustment phenomenon. Journal of Financial Economics, 34, 231-250.

Hong, H., Lim, T., \& Stein, J. (2000). Bad news travels slowly: Size, analyst coverage, and the profitability of momentum strategies. Journal of Finance, 55, 265-295.

Hsu, H., Reed, A., \& Rocholl, J. (2010). The new game in town: Competitive effects of IPOs. Journal of Finance, 65, 495-528.

lannotta, G., Nocera, G., \& Sironi, A. (2013). The impact of government ownership on bank risk. Journal of Financial Intermediation, 22, 152-176.

$\mathrm{Jia}, \mathrm{C}$. (2009). The effect of ownership on the prudential behavior of banks-The case of China. Journal of Banking and Finance, $33,77-87$.

Khwaja, A. I., \& Mian, A. (2005). Do lenders favor politically connected firms rent provision in an emerging financial market. Quarterly Journal of Economics, 120, 1371-1411.

La Porta, R., Lopez-de-Silanes, F., \& Shleifer, A. (2002). Government ownership of banks. Journal of Finance, 57, $265-301$.

López-Espinosa, G., Mayordomo, S., \& Moreno, A. (2017). When does relationship lending start to pay? Journal of Financial Intermediation, 31, 16-29.

Mattes, J. A., Steffen, S., \& Wahrenburg, M. (2013). Do information rents in loan spreads persist over the business cycles? Journal of Financial Services Research, 43, 175-195.

Megginson, W., \& Weiss, K. (1990). Venture capitalist certification in initial public offerings. Journal of Finance, 46, 879-903.

Myers, S. C., \& Majluf, N. S. (1984). Corporate financing and investment decisions when firms have information that investors do not have. Journal of Financial Economics, 13, 187-221.

Pagano, M., Panetta, F., \& Zingales, L. (1998). Why do companies go public? An empirical analysis. Journal of Finance, 53, $27-64$.

Petersen, M. A., \& Rajan, R. G. (1994). The benefits of lending relationships: Evidence from small business data. Journal of Finance, 49, 3-37.

Prilmeier, R. (2017). Why do loans contain covenants? Evidence from lending relationships. Journal of Financial Economics, 123 , 558-579.

Qian, J., Strahan, P. E., \& Yang, Z. (2015). The impact of incentives and communication costs on information production and use: Evidence from bank lending. Journal of Finance, 70, 1457-1493.

Rajan, R. G. (1992). Insiders and outsiders: The choice between informed and arm's-length debt. Journal of Finance, 47, 13671400.

Roberts, M. R., \& Whited, T. M. (2013). Endogeneity in empirical corporate finance. In G. M. Constantinides, M. Harris, \& R. M. Stulz (Eds.), Handbook of the economics of finance (Chapter 7, pp. 493-572). North Holland, the Netherlands: Elsevier.

Salas, V., \& Saurina, J. (2003). Deregulation, market power and risk behavior in Spanish banks. European Economic Review, 47, 1061-1075. 
Santos, J. A., \& Winton, A. (2008). Bank loans, bonds, and information monopolies across the business cycle. Journal of Finance, 63, 1315-1359.

Sapienza, P. (2004). The effects of government ownership on bank lending. Journal of Financial Economics, 72, $357-384$.

Schenone, C. (2010). Lending relationships and information rents: Do banks exploit their information advantages? Review of Financial Studies, 23, 1149-1199.

Sharpe, S. A. (1990). Asymmetric information, bank lending, and implicit contracts: A stylized model of customer relationships. Journal of Finance, 45, 1069-1087.

Shleifer, A., \& Vishney, R. (1994). Politicians and firms. Quarterly Journal of Economics, 109, 995-1025.

Thompson, S. B. (2011). Simple formulas for standard errors that cluster by both firm and time. Journal of Financial Economics, 99, 1-10.

Wang, W., \& Yung, C. (2011). IPO information aggregation and underwriter quality. Review of Finance, 15, $301-325$.

Wei, S., \& Wang, T. (1997). The Siamese twins: Do state-owned banks favor state-owned enterprises in China? China Economic Review, 8, 19-29.

Wu, X., Sercu, P., \& Yao, J. (2009). Does competition from new equity mitigate bank rent extraction? Insights from Japanese data. Journal of Banking and Finance, 33, 1884-1897.

Xu, B., Rixtel, A., \& Wang, H. (2016). Do banks extract informational rents through collateral? Unpublished Working paper. Banco de España, Madrid, Spain.

\section{APPENDIX}

TA B LE A1 Controllers of banks in China

\begin{tabular}{|c|c|c|}
\hline Bank name & Bank type & Actual controller \\
\hline Bank of China & Big Four & $\begin{array}{l}\text { Ministry of Finance (Through Central Huijin } \\
\text { Investment Co.) }\end{array}$ \\
\hline $\begin{array}{l}\text { Industrial and Commercial Bank } \\
\text { of China }\end{array}$ & Big Four & $\begin{array}{l}\text { Ministry of Finance (Through Central Huijin } \\
\text { Investment Co.) }\end{array}$ \\
\hline Agricultural Bank of China & Big Four & $\begin{array}{l}\text { Ministry of Finance (Through Central Huijin } \\
\text { Investment Co.) }\end{array}$ \\
\hline China Construction Bank & Big Four & $\begin{array}{l}\text { Ministry of Finance (Through Central Huijin } \\
\text { Investment Co.) }\end{array}$ \\
\hline China Merchants & Non-Big Four & China Merchants Group \\
\hline $\begin{array}{l}\text { Shanghai Pudong Development } \\
\text { Bank }\end{array}$ & Non-Big Four & $\begin{array}{l}\text { State Asset Supervision and Administration } \\
\text { Commission of Shanghai }\end{array}$ \\
\hline China Everbright Bank & Non-Big Four & Central Huijin Investment Co. \\
\hline Industrial Bank & Non-Big Four & $\begin{array}{l}\text { State Asset Supervision and Administration } \\
\text { Commission of Fujian }\end{array}$ \\
\hline Huaxia Bank & Non-Big Four & $\begin{array}{l}\text { State Asset Supervision and Administration } \\
\text { Commission of Beijing }\end{array}$ \\
\hline
\end{tabular}


TABLEA1 (Continued)

\begin{tabular}{lll}
\hline Bank name & Bank type & Actual controller \\
\hline $\begin{array}{l}\text { China Guangfa Bank } \\
\text { China Bohai Bank }\end{array}$ & Non-Big Four & $\begin{array}{c}\text { State Asset Supervision and Administration } \\
\text { Commission of Guangdong }\end{array}$ \\
$\begin{array}{l}\text { Bank of Communications } \\
\text { China Citic Bank }\end{array}$ & $\begin{array}{c}\text { State Asset Supervision and Administration } \\
\text { Commission of Tianjin }\end{array}$ \\
$\begin{array}{l}\text { NingAn Bank } \\
\text { China Zheshang Bank }\end{array}$ & Non-Big Four & No actual controller \\
Hengfeng Bank & Non-Big Four & No actual controller \\
China Minsheng Bank & Non-Big Four & No actual controller \\
City Commercial Banks & Non-Big Four & No actual controller \\
\hline
\end{tabular}

Note. This table discloses the ultimate controllers of commercial banks in China since 2004 when the Big Four banks first listed on domestic and Hong Kong stock exchanges.

Sources: Banks' annual financial reports, CSMAR, and Bankscope databases.

TABLE A2 Loan distributions in our sample

\begin{tabular}{|c|c|c|c|c|c|c|c|}
\hline \multicolumn{8}{|c|}{ Panel A: Distribution of loan transactions } \\
\hline & & \multicolumn{2}{|l|}{ Full sample } & \multicolumn{2}{|l|}{ Pre-IPO } & \multicolumn{2}{|l|}{ Post-IPO } \\
\hline & & Transactions & Percent & Transactions & Percent & Transactions & Percent \\
\hline \multirow[t]{3}{*}{ SOE } & Big4 & 2,673 & $72.44 \%$ & 1,701 & $76.11 \%$ & 972 & $66.80 \%$ \\
\hline & Non-Big4 & 1,017 & $27.56 \%$ & 534 & $23.89 \%$ & 483 & $33.20 \%$ \\
\hline & Total & 3,690 & $100 \%$ & 2,235 & $100 \%$ & 1,455 & $100 \%$ \\
\hline \multirow[t]{3}{*}{ Non-SOE } & Big4 & 3,719 & $54.27 \%$ & 1,866 & $57.31 \%$ & 1,853 & $51.52 \%$ \\
\hline & Non-Big4 & 3,134 & $45.73 \%$ & 1,390 & $42.69 \%$ & 1,744 & $48.48 \%$ \\
\hline & Total & 6,853 & $100 \%$ & 3,256 & $100 \%$ & 3,597 & $100 \%$ \\
\hline \multicolumn{8}{|c|}{ Panel B: Distribution of loan amount } \\
\hline & & \multicolumn{2}{|c|}{ Full sample } & \multicolumn{2}{|l|}{ Pre-IPO } & \multicolumn{2}{|l|}{ Post-IPO } \\
\hline & & Amount & Percent & Amount & Percent & Amount & Percent \\
\hline \multirow[t]{3}{*}{ SOE } & Big4 & $3,038.18$ & $69.10 \%$ & $1,682.82$ & $73.79 \%$ & $1,355.35$ & $64.05 \%$ \\
\hline & Non-Big4 & $1,358.55$ & $30.90 \%$ & 597.834 & $26.21 \%$ & 760.71 & $35.95 \%$ \\
\hline & Total & $4,396.73$ & $100 \%$ & $2,280.66$ & $100 \%$ & $2,116.07$ & $100 \%$ \\
\hline \multirow[t]{3}{*}{ Non-SOE } & Big4 & $4,644.36$ & $53.82 \%$ & $2,235.86$ & $56.05 \%$ & $2,408.50$ & $51.90 \%$ \\
\hline & Non-Big4 & $3,985.44$ & $46.18 \%$ & $1,753.39$ & $43.95 \%$ & $2,232.05$ & $48.10 \%$ \\
\hline & Total & $8,629.81$ & $100 \%$ & $3,989.25$ & $100 \%$ & $4,640.55$ & $100 \%$ \\
\hline
\end{tabular}

Note. This table shows the shares of different lenders (Big Four vs. others) and borrowers (SOE and non-SOE) in our sample. Panels $A$ and $B$ present the distributions in loan transactions and loan amount, respectively. 
TAB LE A3 Change in ownership structure around IPO

\begin{tabular}{|c|c|c|c|c|}
\hline \multicolumn{5}{|c|}{ Panel A: Change of the ultimate controller around IPO } \\
\hline & \multicolumn{2}{|c|}{ Period relative to IPO date (years) } & \multirow{2}{*}{$\begin{array}{l}\text { New state } \\
\text { controller }\end{array}$} & \multirow{2}{*}{$\begin{array}{l}\text { No. of } \\
\text { firms }\end{array}$} \\
\hline & {$[-1,1]$} & {$[0,3]$} & & \\
\hline SOE & 0 & 4 & 4 & 150 \\
\hline Non-SOE & 0 & 3 & 0 & 345 \\
\hline All & 0 & 7 & 4 & 495 \\
\hline \multicolumn{5}{|c|}{ Panel B: Changes in state ownership for SOEs around IPO } \\
\hline & \multicolumn{3}{|c|}{ State ownership pre-IPO } & \\
\hline Range of change & $<50 \%$ & {$[50 \%, 90 \%]$} & $>90 \%$ & All \\
\hline$[0,100 \%]$ & 20 & 0 & 0 & 20 \\
\hline$[-20 \%, 0]$ & 13 & 21 & 2 & 36 \\
\hline$[-40 \%,-20 \%]$ & 3 & 25 & 51 & 79 \\
\hline$[-100 \%,-40 \%]$ & 0 & 5 & 10 & 15 \\
\hline
\end{tabular}

Note. Panel A shows the number of firms whose ultimate controller has changed around IPO. Panel B shows the changes in state ownership for SOEs around IPO.

Sources: CSMAR database, Wind database, and firms' prospectuses and annual reports. 